\title{
Primary cell cultures as models of prostate cancer development
}

\author{
D M Peehl
}

Department of Urology, Stanford University School of Medicine, Stanford, California, USA

(Requests for offprints should be addressed to D Peehl; Email: dpeehl@stanford.edu)

\begin{abstract}
This review focuses on primary cultures of human prostatic epithelial cells and their applications as models of normal and malignant biological behavior. Current abilities to culture cells from normal tissues, from premalignant dysplastic lesions (prostatic intraepithelial neoplasia), from primary adenocarcinomas, and from metastases are described. Evidence for representation of the interrelated cells of the normal prostatic epithelium - stem cells, basal epithelial cells, secretory epithelial cells, transit amplifying cells and neuroendocrine cells - in primary cultures is presented. Comparisons between normal and cancer-derived primary cultures are made regarding biological activities relevant to carcinogenesis, such as proliferation, apoptosis, differentiation, senescence, adhesion, migration, invasion, steroid hormone metabolism, other metabolic pathways and angiogenesis. Analyses of tumor suppressor activity, differential gene expression and cytogenetics in primary cultures have revealed changes relevant to prostate cancer progression. Preclinical studies with primary cultures have provided information useful for designing new strategies for chemoprevention, chemotherapy, cytotoxin therapy, radiation therapy, gene therapy and imaging. While the behavior of normal primary cultures is often used as a basis for comparison with established, immortal prostate cancer cell lines, the most informative studies are performed with donor-matched pairs of normal and malignant primary cultures, grown under identical conditions. Challenges that remain to be addressed if the full potential of primary cultures as a model system is to be realized include isolation, culture and characterization of stem cells, improved methodology to induce or maintain a fully differentiated, androgen-responsive phenotype, and identification of cell surface antigens or other markers with which to purify pure populations of live cancer or premalignant cells apart from non-malignant epithelial cells prior to culture.
\end{abstract}

Endocrine-Related Cancer (2005) 12 19-47

\section{Introduction}

Historically, in vitro cultures of human prostatic cells have been limited in availability and scope compared with those from many other organs. Three spontaneously established cell lines, PC-3, DU 145 and LNCaP, are by far the most commonly used cell culture models of prostate cancer (Bosland et al. 1996). Although other prostate cancer cell lines are available, recent studies revealed that many of these are in fact derivatives of the three aforementioned cell lines or other nonprostatic lines (van Bokhoven et al. 2003). The few bona fide cell lines, almost all derived from metastases, do not span the range of prostate cancer phenotypes, and in particular are not representative of primary adenocarcinomas of the prostate. Furthermore, the question of how extensively long-term culture alters the biological properties of cell lines is always lurking. For these and other reasons, primary cultures of malignant prostatic cells and their normal epithelial counterparts are sought.

During the past 20 years, many of the technical hurdles involved in growing primary cultures of human prostatic epithelial cells have been overcome, and a variety of more or less similar methods have been reported (for review see Peehl \& Sellers 2002). Most primary cultures are derived from radical prostatectomy specimens, but methods for culturing cells from needle biopsies, from fluid obtained by prostatic massage, and from bone marrow aspirates have been described. The use of primary cultures is becoming 
more widespread, especially with the advent of commercial availability of normal cells, and they have been used in many diverse studies. The growing body of information about the molecular and cellular features of prostate tissues has permitted more extensive and definitive characterization of primary cultures. This article will review the characteristics of primary cultures of human prostatic epithelial cells, with special emphasis on their ability to model processes involved in prostatic carcinogenesis. Information obtained from primary cultures derived from benign prostatic hyperplasia (BPH) will not for the most part be included in this review. For a discussion of the molecular and cellular biology of BPH and the properties of primary cultures derived from $\mathrm{BPH}$ tissues, the reader is referred to a recent review (Lee $\&$ Peehl 2004). Although generation of primary cultures of mouse prostatic cells is becoming more frequent, this article also will not include any information about rodent cell culture models. Finally, although cell lines created by introduction of immortalizing genes into primary cultures are often used as representative of the normal or cancer cells of origin (for reviews see Webber et al. 1996, 1997), studies with these cells also will not be included here because the relevance of these lines to normal or cancer biology is controversial.

\section{Normal prostatic epithelial cells}

The normal prostatic epithelium is composed of five inter-related cell types - stem cells, basal epithelial cells, transit amplifying cells, neuroendocrine cells and secretory epithelial cells. The ability of these cell types to be maintained in vitro is discussed below.

\section{Basal epithelial cells}

Basal cells form a single layer on the basement membrane underlying the normal prostatic epithelium. Classic markers of basal epithelial cells of normal glands of the human prostate are cytokeratins 5 and 14 (Brawer et al. 1985). Most investigators report that almost every cell in primary cultures derived from normal tissues expresses these basal cytokeratins (Brawer et al. 1986, Gao et al. 2001). Proliferation is also confined to the basal cells of normal tissues (McNeal et al. 1995, Kyprianou et al. 1996) and, similarly, primary cultures of normal prostatic epithelial cells are proliferative.

In 1994, a list of genes whose expression had been localized to basal cells of normal prostatic tissues up to that time was published (Ware 1994). More recently,
Liu et al. (2002) prepared a cDNA expression library from basal cells purified directly from enzymatically digested tissues and identified genes expressed by these cells. Of these basal-associated genes, only a subset has been evaluated in cultured cells. One of the basalassociated genes expressed by primary cultures of normal prostatic epithelial cells is the transcription factor ETS-2 (Liu et al. 1997a). ETS-2 positively regulates the expression of maspin, a protease inhibitor that is also found in basal cells of prostatic tissues and in cultured normal cells (Zhang et al. 1997). Maspin has gained attention as a putative tumor suppressor gene (Sheng et al. 1996), and microarray analyses have pinpointed maspin as a gene differentially expressed between non-malignant and prostate cancer tissues (Chen et al. 2003).

B cell translocation gene 2 (BTG2), a p53 target gene that negatively regulates cell cycle progression, is also expressed in basal cells of prostatic glands and in primary cultures from normal tissues, reaching its highest level in quiescent cells (Ficazzola et al. 2001). BTG2 is absent in premalignant dysplastic glands and in prostate cancer, perhaps related to loss of growth control in these entities. Other proteins localized to the basal epithelia of prostatic glands and expressed by primary cultures of normal prostatic epithelial cells include the growth factor receptor ErbB1 (Adam et al. 1999), CD44 (Liu et al. 1997b), and the estrogen receptor (ER)- $\beta$ (Leav et al. 2001, Pasquali et al. 2001).

Basal epithelial cells in vitro should theoretically make a basement membrane, but few studies have investigated the production of basement membrane or other extracellular matrix proteins in detail. Cussenot et al. (1994) reported that cultures of normal prostatic epithelial cells did not make the basement membrane protein, type IV collagen. Cultured prostatic epithelial cells aberrantly make the mesenchymal-associated extracellular matrix protein, vimentin, but this is true of most cultured epithelial cells and is apparently a common artifact of in vitro propagation (Sherwood et al. 1989, Kooistra et al. 1995, Goossens et al. 2002).

Overall, many features of primary cultures of epithelial cells derived from normal prostatic tissues are consistent with a basal-like phenotype - proliferative ability, expression of cytokeratins 5 and 14, and expression of other basal-associated genes (Table 1).

\section{Secretory epithelial cells}

Differentiated secretory epithelial cells line the lumens of normal prostatic glands. Whereas basal cells express cytokeratins 5 and 14, secretory cells express cytokeratins 8 and 18 (Brawer et al. 1985). A subpopulation of 
Table 1 Basal cell markers expressed by primary cultures of normal prostatic epithelial cells

\begin{tabular}{|c|c|}
\hline Marker & Reference \\
\hline Cytokeratin 5 & $\begin{array}{c}\text { Brawer et al. (1986), } \\
\text { Gao et al. (2001) }\end{array}$ \\
\hline Cytokeratin 14 & $\begin{array}{c}\text { Brawer et al. (1986), } \\
\text { Gao et al. (2001) }\end{array}$ \\
\hline ETS-2 & $\begin{array}{l}\text { Liu et al. (1997a), } \\
\quad \text { Liu \& Peehl (2001) }\end{array}$ \\
\hline Maspin & Zhang et al. (1997) \\
\hline BTG2 & Ficazzola et al. (2001) \\
\hline ErbB1 & Adam et al. (1999) \\
\hline CD44 & $\begin{array}{l}\text { Liu et al. (1997b), } \\
\quad \text { Liu \& Peehl (2001) }\end{array}$ \\
\hline $\mathrm{ER} \beta$ & $\begin{array}{l}\text { Leav et al. (2001), } \\
\text { Davis et al. (2002) }\end{array}$ \\
\hline p63 & $\begin{array}{l}\text { Signoretti et al. (2000), } \\
\text { Davis et al. (2002) }\end{array}$ \\
\hline c-Met & You et al. (2003) \\
\hline $17 \beta-H S D$ & He et al. (2003) \\
\hline Epithelial glycoprotein & Liu \& Peehl (2001) \\
\hline Collagenase & Liu \& Peehl (2001) \\
\hline Zinc- $\alpha_{2}$-glycoprotein & Liu \& Peehl (2001) \\
\hline Fibronectin receptor- $\beta$ & Liu \& Peehl (2001) \\
\hline SEF2 & Liu \& Peehl (2001) \\
\hline CD49b & Liu \& Peehl (2001) \\
\hline CD49f & Liu \& Peehl (2001) \\
\hline CD55 & Liu \& Peehl (2001) \\
\hline CD59 & Liu \& Peehl (2001) \\
\hline CD95 & Liu \& Peehl (2001) \\
\hline CD104 & Liu \& Peehl (2001) \\
\hline
\end{tabular}

cells in normal primary cultures expresses cytokeratins 8 and 18 (Brawer et al. 1986, van Leenders et al. 2000, Gao et al. 2001, Goossens et al. 2002). However, since these same cells simultaneously express the basal cell cytokeratins 5 and 14, this pattern of cytokeratin expression suggests lack of complete differentiation. Cells in the prostatic epithelium that express markers of both basal and secretory cells are referred to as intermediate cells or transit amplifying cells (Bonkhoff et al. 1994), and their significance is discussed in a forthcoming section. Cytokeratin 19, expressed by both basal and secretory cells of the prostatic epithelium, is also expressed by cultured cells (Peehl et al. 1996, Robinson et al. 1998).

15-Lipoxygenase (LOX)-2 is a secretory cell-specific enzyme (Shappell et al. 1999) that is expressed in primary cultures of normal prostatic cells (Tang et al. 2002). Decreased expression of 15-LOX-2 in prostate cancer suggests tumor suppressor functions (Jack et al. 2000), and this concept is further supported by antiproliferative effects of 15 -LOX-2 metabolites on normal prostatic epithelial cells (Tang et al. 2002).
A hallmark of prostatic secretory cells is the expression of androgen receptor (AR) and prostatespecific antigen (PSA) (Leav et al. 1996). Most investigators report that normal primary cell cultures express low or no AR or PSA and do not respond to androgen or respond minimally (for review see Peehl \& Sellers 2002). Methylation of the gene promoter has been ruled out as the mechanism responsible for lack of expression of AR in normal primary cultures, and in fact AR mRNA can be found in these cells (Grant et al. 1996, Jarrard et al. 1998, Tekur et al. 2001). This phenotype is reminiscent of basal epithelial cells in the prostate, in which AR transcripts are present but are not translated into protein (Leav et al. 1996). Therefore, lack of robust expression of AR and PSA is another feature of primary cultures that more resembles a basal than a secretory cell phenotype. However, despite the absence of AR protein, primary cultures are proving useful for studies of AR coregulators. One of these, ARA70, was noted to be expressed at high levels in normal primary cultures compared with prostate cancer cell lines (Tekur et al. 2001).

Although investigators have attempted to achieve a fully differentiated secretory phenotype of prostate cells in vitro, success has been limited. While retinoic acid increases levels of the secretory cell cytokeratins 8 and 18 in primary cultures, the cells continue to express basal cell cytokeratins, and other differentiation markers such as PSA remain low (Peehl et al. 1994b, Goosens et al. 2002). Continuous exposure to collagenase was reported to retain androgen response (Mitchen et al. 1997), but this methodology has not been tested further. Culture in medium containing fibroblast growth factor (FGF)-7 was said to increase AR mRNA levels in normal cells, but protein was not measured (Planz et al. 2001).

Modest success at promoting differentiation has been achieved by three-dimensional culture in Matrigel (Fong et al. 1991, Hudson et al. 2000). Epithelial cells grown on collagen gels containing stromal cells also were reported to express PSA and another differentiation marker, prostate-specific membrane antigen (PSMA) (Hall et al. 2002). A recent report by Lang et al. (2001) revealed that serum may be the secret ingredient that has been missing in culture media used to promote differentiation. In three-dimensional cultures in Matrigel in the absence of serum and stromal cells, solid masses of cellular spheres formed from normal prostatic epithelial cells isolated directly from tissues or after short-term culture. The addition of $2 \%$ serum induced formation of a lumen surrounded by one or two layers of cuboidal cells, and cytokeratins 5, 14 , and 18 were variably expressed. PSA and AR were 
weakly expressed. Addition of stromal cells, androgen and estrogen induced polarization of the epithelium. Interestingly, these polarized structures could be formed only by CD44+ (basal) cells selected from the original tissue digests, while CD44- cells were unable to create these structures. While exact reproduction of basal and secretory cell phenotypes was not achieved, this appears to be a significant step forward.

As another approach to study secretory cells in culture, Liu et al. (1997b) isolated almost pure populations of live basal and secretory cells from enzymatically digested tissues, taking advantage of differential expression of CD44 and CD57 cell surface antigens by basal and secretory cells respectively. After being sorted by flow cytometry, the separated cell populations were cultured overnight and characterized. The cell populations continued to express many of the genes of the basal or secretory cell transcriptomes that these investigators had previously identified. However, expression of PSA was unexpectedly absent from CD57 + cells, despite the continued expression of other secretory cell genes. Only when the secretory cells were co-cultured with prostatic stromal cells was PSA expression maintained. Interestingly, stromal cells also induced PSA expression in CD57- (basal) cells. Altogether, these results add to the overall impression that stromal-epithelial interactions are indeed critical for prostatic epithelial cell differentiation, and that secretory cells are derived from a basal cell precursor.

Secretory cell markers that are expressed by primary cultures of normal prostatic epithelial cells are summarized in Table 2.

\section{Neuroendocrine cells}

Neuroendocrine cells make up a small percentage of the normal prostatic epithelium (Bonkhoff 1998). A variety of evidence points to the origin of these neuroendocrine cells from a pluripotent (stem?) cell that also generates secretory cells in the prostate (Bonkhoff 1998). The biological role of neuroendocrine cells in the prostate is not clear, but it has been hypothesized that the cytokines secreted by these cells influence growth or differentiation of surrounding epithelial cells (Abrahamsson 1999). Neuroendocrine differentiation in primary cultures has not been widely investigated, but Rumpold et al. (2002) reported the presence of non-proliferating cells that coexpressed cytokeratins 5,14 and 18 , as well as the neuroendocrine marker chromogranin A, in primary cultures of prostatic epithelial cells. Table 3 lists neuroendocrine markers expressed in primary cultures.
Table 2 Secretory (luminal) cell markers expressed by primary cultures of normal prostatic epithelial cells

\begin{tabular}{|c|c|}
\hline Marker & Reference \\
\hline Cytokeratin 8 & $\begin{array}{l}\text { Brawer et al. (1985), } \\
\text { van Leenders et al. (2000), } \\
\text { Gao et al. (2001), } \\
\text { Goosens et al. (2002) }\end{array}$ \\
\hline Cytokeratin 18 & $\begin{array}{l}\text { Brawer et al. } 1985, \\
\text { van Leenders et al. (2000), } \\
\text { Gao et al. (2001), } \\
\text { Goosens et al. (2002) }\end{array}$ \\
\hline 15-LOX-2 & Tang et al. (2002) \\
\hline $\operatorname{AR}(+/-)$ & Reviewed in Peehl \& Sellers (2002) \\
\hline PSA (+/-) & Reviewed in Peehl \& Sellers (2002) \\
\hline ARA70 & Tekur et al. (2001) \\
\hline PSMA (+/-) & Hall et al. (2002) \\
\hline CD9 & Liu \& Peehl (2001) \\
\hline CD24 & Liu \& Peehl (2001) \\
\hline CD10 & Liu \& Peehl (2001) \\
\hline CD13 & Liu \& Peehl (2001) \\
\hline CD26 & Liu \& Peehl (2001) \\
\hline CD107a & Liu \& Peehl (2001) \\
\hline CD117 & Liu \& Peehl (2001) \\
\hline
\end{tabular}

\section{Transit amplifying cells}

Simultaneous expression of basal cell cytokeratins 5 and/or 14 and secretory cell cytokeratins 8 and/or 18, as occurs in a subset of cells in primary cultures, is also seen in a small number of cells in the prostatic epithelium (Bonkhoff et al. 1994). Such cells have been referred to as 'transit amplifying cells' or 'intermediate' cells. These proliferative cells express features of basal and secretory and/or neuroendocrine cells, and combinations thereof. It has been proposed that these transit amplifying cells are stem-like cells or progenitor cells that are in the process of generating differentiated cell populations but have not yet completely committed to one particular lineage. The phenotype of primary cultures — proliferative and simultaneously expressing markers of both basal and secretory cells, and possibly neuroendocrine cells most resembles that of transit amplifying cells (for review see Uzgare et al. 2004). For example, Tran et al. (2002) described a subpopulation in primary cultures of normal prostatic epithelial cells that coexpressed

Table 3 Neuroendocrine markers expressed by primary cultures of normal prostatic epithelial cells

\begin{tabular}{ll}
\hline Marker & \multicolumn{1}{c}{ Reference } \\
\hline Chromogranin A & Rumpold et al. (2002) \\
Neuron-specific enolase & Liu \& Peehl (2001) \\
\hline
\end{tabular}


prostate stem cell antigen and CD44 (basal markers), basal and secretory cell cytokeratins, and AR and PSA (secretory markers). These cells did not express the basal marker, p63. These investigators interpreted their findings as evidence of an intermediate population of cells in transition from a basal to a terminally differentiated secretory phenotype. Garraway et al. (2003) provided a similarly detailed analysis of intermediate cells in primary cultures.

Analysis of CD antigens also suggested an intermediate phenotype of cultured prostatic epithelial cells (Liu \& Peehl 2001). Liu \& True (2002) cataloged expression of $\mathrm{CD}$ antigens by constituent cell types of the prostate and identified $\mathrm{CD}$ antigens on secretory cells and on basal cells. Normal primary cultures expressed a number of $\mathrm{CD}$ antigens in common with basal epithelial cells, but also expressed many CD antigens found on secretory cells, again demonstrating an intermediate phenotype of cultured cells.

The most comprehensive view of the basal- vs secretory-like phenotype of cultured normal prostatic epithelial cells comes from a comparison of basal and secretory cell transcriptome sets to gene sequences in a cDNA library made from cultured normal cells (Liu et al. 2002). There was a higher representation of basal cell genes $(12.3 \%)$ than secretory cell genes $(6.7 \%)$, showing again the intermediate nature of the cells but suggesting that, overall, the cells are more basaloid than secretory.

\section{Stem cells}

Schalken \& van Leenders (2003) recently discussed current views regarding stem cells in the prostate. Prostatic stem cells have not been definitively identified in tissues or in culture. A recent study provided evidence that stem cells in the mouse prostate are located proximally (Tsujimura et al. 2002), but whether this is true in the human prostate is unknown. It is believed that stem cells reside in the basal epithelial layer. In primary cultures of human prostatic epithelial cells established by Hudson et al. (2000), two types of clones were observed. One type was described as small and composed of enlarged, senescent-like cells. The other type was typically large and composed of numerous small, proliferating cells. These investigators proposed that the large proliferative colonies developed from stem cells, but other interpretations are possible.

Expression of $\alpha_{2} \beta_{1}$-integrin is linked to epithelial stem cells. This integrin was used as a marker for sorting putative stem cells from the human prostate and culturing for evaluation (Collins et al. 2001). First, expression of $\alpha_{2} \beta_{1}$-integrin in prostatic epithelium in tissues was evaluated, and about $1 \%$ of basal cells highly expressed $\alpha_{2} \beta_{1}$-integrins. Selection of cells from digested tissues that adhered to type I collagen resulted in a cell population that highly expressed $\alpha_{2^{-}}, \alpha_{3^{-}}$and $\alpha_{6}$-integrins. Rapidly adhering cells had a high colonyforming efficiency and a basal-like phenotype (cytokeratin 5/14+, PSA -, small subset cytokeratin $18+$ ). Three types of colonies formed: those that did not grow for about a week, then proliferated and formed large colonies, those that grew rapidly from the onset, and those that formed small terminal colonies. Cells that were selected by the ability to attach to type I collagen within $5 \mathrm{~min}$ and were then combined with stromal cells and injected into mice occasionally formed epithelial structures with both basal and secretory (PSA/AR + ) cells, considered as evidence of stem cell activity.

Expression of telomerase is associated with stem cells, which have extended proliferative ability and are long-lived if in fact not immortal. Therefore, the presence of telomerase in primary cultures is suggestive of the presence of stem cells. Low but detectable telomerase activity in normal prostatic primary cultures has been reported by some investigators (Belair et al. 1997, Soda et al. 2000), corresponding with evidence of telomerase in basal cells of the normal prostatic epithelium (Bettendorf et al. 2003).

It is likely, if stem cells exist in primary cultures established and maintained under standard conditions, that they are lost with serial passage or overgrown by non-stem cells. Gao et al. (2001) found that organoids of prostatic epithelial cells, digested from normal tissues and immediately placed in Matrigel and injected s.c. into mice, exhibited stem cell-like activity in that they formed acini with basal and secretory cells in an androgen-dependent manner. But if cells were isolated and grown in primary culture prior to implantation in mice, they remained as small nests of basal cells. Unlike the organoids, the previously cultured cells did not induce infiltration and smooth muscle differentiation of mesenchymal cells, an event that may be critical for maintenance and function of stem cells.

Putative markers of stem cells expressed by primary cultures are summarized in Table 4.

Table 4 Putative markers of stem cells expressed by primary cultures of normal prostatic epithelial cells

\begin{tabular}{ll}
\hline Marker & \multicolumn{1}{c}{ Reference } \\
\hline$\alpha_{2} \beta_{1}$ integrin & Collins et al. (2001) \\
Telomerase & Belair et al. (1997), Soda et al. (2000) \\
\hline
\end{tabular}




\section{Biological activities of normal primary cultures \\ Proliferation}

Normal prostatic epithelial cells are typically grown in serum-free medium and reported doubling times range from 16 to $36 \mathrm{~h}$ (for review see Peehl \& Sellers 2002). While this rate of proliferation is much more rapid than that of epithelia in the prostate itself (with a turnover time of $\sim 2$ years), proliferation can be modulated by reducing the concentrations of mitogens or other components in the medium to attain a more physiological rate of replication (Cussenot et al. 1994).

Several previous reviews have discussed growth regulatory factors for prostatic epithelial cells in depth (Byrne et al. 1996, Culig et al. 1996, Peehl 1996, Ittman \& Mansukkani 1997, Djakiew 2000), so a detailed presentation will not be given here. Mitogens for normal prostatic epithelial cells are similar to those for other types of epithelial cells, and include members of the epidermal growth factor (EGF) family, FGF family, nerve growth factor family and insulin-like growth factors (IGFs). Growth-inhibitory factors include transforming growth factor (TGF)- $\beta$, vitamin $\mathrm{D}$, and retinoids. Studies with primary cultures have shown that many growth factors are secreted by normal prostatic epithelial cells, and either exert autocrine effects if the cognate receptor is expressed by the epithelial cells, or mediate paracrine effects on cognate receptors present in prostatic stromal cells. Similarly, many growth factors have been identified that are secreted by stromal cells and exert paracrine effects on the epithelium. Primary cultures have not yet revealed factors that mediate stromal-epithelial interactions induced by androgen (andromedins), or factors that maintain homeostasis between basal and secretory epithelial cells.

Recently, additional growth factor receptors and their ligands have been studied in normal prostatic epithelial cells. Receptors for colony-stimulating factor (CSF)-1 were expressed, albeit at relatively low levels (Ide et al. 2002). Parallel studies of mouse prostate development demonstrated epithelial expression of CSF-1R during the protrusion of prostatic buds from the urogenital sinus and during the prepubertal and androgen-driven proliferative expansion and branching of the glands, suggesting a developmental role for this tyrosine kinase. Immunohistochemical analysis of CSF-1R in the adult human prostate showed low levels of expression in normal epithelia, with a trend towards increased expression in dysplasia and cancer. Further studies may more definitively point to a role for $\mathrm{CSF}-1 \mathrm{R}$ in prostate cancer progression.

Another receptor of recent interest is the peroxisome proliferator-activated receptor (PPAR)- $\gamma$, a member of the nuclear hormone receptor superfamily. Agonists of PPAR $\gamma$ have shown some clinical activity in pilot studies on prostate cancer (Koeffler 2003). Treatment of normal prostatic epithelial cells with the PPAR $\gamma$ agonist, rosiglitazone, resulted in growth suppression and induction of a unique phenotype whose characteristics remain to be more fully elucidated ( $\mathrm{Xu}$ et al. 2003).

\section{Apoptosis}

Similar to the low rate of proliferation in the normal prostatic epithelium, apoptosis occurs in less than $1 \%$ of the homeostatic epithelium (Kyprianou et al. 1996). Many studies suggest that primary cultures of normal prostatic epithelial cells are relatively resistant to the induction of apoptosis. For example, normal cells are resistant to apoptosis-inducing effects of tumor necrosis factor (TNF)- $\alpha$, despite the presence of TNF- $\alpha$ receptors (Subbarayan et al. 2001, Chopra et al. 2004). In studies of resistant normal primary cultures and resistant prostate cancer cell lines vs responsive cell lines, resistance to apoptosis correlated with activation of IKK- $\alpha$ and translocation of NF- $\kappa B$ to the nucleus.

TGF $\beta$ has been implicated as an apoptotic factor in the prostatic epithelium. TGF $\beta$ increases after androgen ablation, and treatment with TGF $\beta$ partially but not entirely induces epithelial apoptosis to the same extent as that caused by deprivation of androgen (Martikainen et al. 1990). Nevertheless, in primary cultures of normal prostatic epithelial cells, TGF $\beta$ typically induces growth arrest and other phenotypic changes, but not apoptosis (Peehl et al. 1994b). However, Sutkowski et al. (1992) reported that TGF $\beta$ induced apoptosis in primary cultures if the potent mitogen and survival factor, EGF, was deleted from the culture medium. This finding suggests that the activity of TGF $\beta$ and/or the ability to undergo apoptosis in general depends on the local milieu of growth and survival factors.

One exception to overall resistance to apoptosis is the sensitivity of normal prostatic epithelial cells to TNF-related apoptosis-inducing ligand (TRAIL), a pro-apoptotic cytokine at one time believed to selectively kill cancer cells without harming normal ones. However, normal prostatic epithelial cells are very sensitive to induction of apoptosis by TRAIL (Nesterov et al. 2002). Interestingly, these cells have comparable levels of TRAIL receptors (DR4 and 
DR5) to some other types of cells that are resistant to TRAIL. The unusual sensitivity may instead be due to deficiency in anti-apoptotic decoy receptors (DcR1 and DcR2).

Another condition that reportedly causes apoptosis of normal prostatic epithelial cells is deprivation of growth factors (Tang et al. 1998). Prostate cancer cell lines and primary cultures of cancer cells were seemingly much more resistant to this deprivation. The differential response was attributed to upregulation of p53 and pro-apoptotic proteins $\mathrm{Bax} / \mathrm{Bad} / \mathrm{Bak}$, concurrent with downregulation of p21 and low levels of bcl-2, in the normal cells. Additional discussion of apoptosis in normal vs malignant prostatic epithelial cells can be seen in a forthcoming section.

\section{Senescence}

Cellular senescence is proposed to be a growth-limiting block that cells must overcome in order to become tumorigenic. It has been suggested that induction of senescence in cancer cells may be an effective therapeutic strategy (Berns 2002). Primary cultures have been used to delineate molecular mechanisms of senescence in prostate cells. Epithelial cells cultured from normal tissues are mortal and are capable of about 30 population doublings before undergoing replicative senescence (Iype et al. 1998, Schwarze et al. 2001, Peehl \& Sellers 2002), although one group described extended culture of normal cells $(\sim 50$ population doublings) by continuous treatment with interstitial collagenase (Mitchen et al. 1997). In the early 1990s, Merchant (1990) described cells grown by his methods as going into crisis, then becoming rapidly proliferating. However, this phenomenon has not been described by any other investigator with one exception (Sinisi et al. 2002). It should be noted that, until recently, most normal cells were derived from men $\sim 60$ years of age or older, undergoing radical prostatectomy or other surgical procedures. Although normal prostatic epithelial cells from young men are now commercially available, a detailed examination of their lifespan in culture has not been reported, and it is possible that they are longer-lived.

The characteristics of serially passaged normal prostatic epithelial cells approaching and undergoing senescence have been described. Increased expression and phosphorylation of $\mathrm{p} 16^{\mathrm{INK} 4 \mathrm{a}}$ accompanies replicative senescence (Sandhu et al. 2000), and Schwarze et al. (2001) found that alterations in either $\mathrm{p} 16^{\mathrm{INK} 4 \mathrm{a}}$ or pRB are necessary in order for prostatic epithelial cells to bypass senescence. Recent studies further defined the role of cyclin-dependent kinase inhibitors in the growth arrest that occurs at senescence of prostatic epithelial cells (Schwarze et al. 2001). While p16 ${ }^{\mathrm{INK} 4 \mathrm{a}}$ increased, other proteins including $p R B$, cyclin $\mathrm{D}$, $\mathrm{p} 19^{\mathrm{INK} 4 \mathrm{~d}}$, and $\mathrm{p} 27^{\mathrm{KIP} 1}$ declined. A phase of presenescent growth arrest was identified that was accompanied by elevation of Cdk2-associated activity, and transient elevation of $\mathrm{p} 53, \mathrm{p} 21^{\mathrm{CIP} 1}$, and $\mathrm{p} 15^{\mathrm{INK} 4 \mathrm{~b}}$. A noteworthy finding in this study was that $\mathrm{p} 57^{\mathrm{KIP} 2}$ levels increased in senescent human uroepithelial cells but not in prostatic cells, suggesting cell-specific molecular regulation of senescence. Another interesting point is that senescence of prostatic epithelial cells (and urothelium) occurs by telomere-independent mechanisms (Belair et al. 1997). Microarray analysis has led to a genetic profile of senescent normal human prostatic epithelial cells (Schwarze et al. 2002). Secretion of interleukin (IL)- $1 \alpha$ and IL-8 is also associated with senescent prostatic epithelial cells (Castro et al. 2004).

Interferons (IFNs), a family of cytokines, have been implicated in senescence of prostatic epithelial cells. Serial analysis of gene expression revealed that the expression of a set of IFN-activated genes is upregulated during the onset of senescence (Untergasser et al. 2002), and Xin et al. (2003) recently showed that IFI 16, a member of the IFN-inducible p200-protein family, contributes to senescence of normal prostate cells. These investigators also observed that prostate cancer cell lines either did not express IFI 16 or expressed a variant form, and that overexpression of IFI 16 inhibited growth of cancer cell lines and induced a senescent-like phenotype. It is also interesting to note that loss of expression of IFN-activatable genes correlated with development of cancer in an experimental model of prostate tumor progression (Shou et al. 2002). Studies such as these provide insight into the role of senescence as a tumor suppressor.

Whether senescence actually occurs in the human prostate is an interesting question. Two groups have reported the presence of prostatic epithelial cells expressing senescence-associated $\beta$-galactosidase, but only in prostates with abundant BPH (Choi et al. 2000, Castro et al. 2003). The role of senescence in physiological and pathological processes remains an important topic of study.

\section{Adhesion, migration and invasion}

Cell motility and migration are essential for morphogenesis of the ductal system of the prostate, and for continuous regeneration of the epithelium in the adult. Increased migration and invasion and decreased adhesion are believed to be instrumental in cancer 
progression. Therefore, these activities have been studied in normal cells to better understand physiological processes as well as the impact of changes that occur in cancer.

Migration of normal prostatic cells in culture is very dependent on the composition of the culture medium. For example, in medium containing EGF, cells are very migratory and form colonies consisting of widely spread cells. In contrast, in medium without EGF or with FGF-7 replacing EGF, cells remain in coherent islands with extensive cellular adhesions (Peehl \& Rubin 1995). Hepatocyte growth factor (HGF), secreted by prostatic stromal cells, is a potent stimulator of migration and invasion of normal prostatic cells in culture (You et al. 2003). The cellular receptor of HGF, c-Met, is known to be present on basal epithelial cells in the prostate, and HGF is believed to regulate branching morphogenesis via paracrine mechanisms (Zhang \& Vande Woude 2003). It is interesting that c-Met has also been localized to transit amplifying cells in the prostate, while c-Met is absent on secretory cells, suggesting a need for migration of basal and transit but not fully differentiated cells (van Leenders et al. 2002). c-Met is expressed as well on prostate cancer cells, and HGF and overexpression of c-Met have been implicated in metastatic potential (Humphrey et al. 1995, Pisters et al. 1995, Zhu \& Humphrey 2000). An adenovirus expressing a c-Met ribozyme was shown to inhibit growth and metastasis of a prostate cancer xenograft model, further showing the important role of this receptor in cancer (Kim et al. 2003).

The membrane-anchored serine protease prostasin is believed to suppress invasion. Expressed in normal prostatic epithelia but downregulated in high-grade cancer, prostasin is expressed by primary cultures of normal cells but not by several of the prostate cancer cell lines (Chen et al. 2004). Hypermethylation of the promoter sequence of the gene is responsible at least in part for lower expression in cancer cells. In contrast to high expression of the invasion suppressor, prostasin, in normal cells, MUC18, a cell adhesion molecule associated with metastatic ability, is expressed at low levels in normal prostatic cell cultures but at high levels in several prostate cancer cell lines (Wu et al. 2001).

\section{Tumor suppressors}

The most widely studied tumor suppressor is p53 (Balint \& Vousden 2001). As in many other types of normal human epithelial cells (Flatt et al. 1998, Meyer et al. 1999), p53 activation by DNA-damaging agents is attenuated in primary cultures of normal prostatic epithelial cells (Girinsky et al. 1995, Bromfield et al. 2003). This attenuation has been attributed to a need for progenitor or stem-like cells to repress p53 activity so as not to self-eliminate through p53-mediated apoptosis (Dumble et al. 2001). One group has reported elevation of $\mathrm{p} 53$ and apoptosis in normal prostatic epithelial cells upon growth factor withdrawal, which did not occur in primary cultures from cancer (Tang et al. 1998). Further discussion of p53 in relation to prevention and therapy of prostate cancer is included in forthcoming sections.

The p53 homolog, p63, is present in the basal epithelium of the prostate and in primary cell cultures from normal tissues, which express predominantly the $\Delta \mathrm{Np} 63 \alpha$ isotype (Signoretti et al. 2000, Davis et al. 2002). The $\Delta \mathrm{Np} 63 \alpha$ isotype acts as a p53-dominantnegative, raising the possibility that expression of this p63 isotype is related to the attenuated activity of p53 in normal cells. Interestingly, p63 expression disappears in senescent cultures of prostatic epithelial cells (Davis et al. 2002), at a time when p53 increases (see the discussion of senescence above). For the most part, p63 expression is absent in prostate cancer (Signoretti et al. 2000, Davis et al. 2002), although expression in primary cultures from tumors has not been determined. A role in stem cell functions has been attributed to p63 (McKeon 2004), but its functions in prostatic epithelial cells are undefined.

Another gene, DOC-2/DAB2, has tumor suppressor activity in prostate cancer cell lines, and studies with normal prostatic epithelial cells have suggested that this protein acts by binding to and inactivating c-Src, which is involved in the Ras-mitogen-activated protein kinase pathway (Zhou et al. 2003).

\section{Dysplasia}

Dysplasia, also known as prostatic intraepithelial neoplasia, is considered to be a premalignant lesion in the prostate (McNeal 1988, Bostwick et al. 1996). Histologically, dysplasia is typified by enlarged nuclei, attenuation of the basal epithelial cell layer, proliferation of secretory cells, and aberrant differentiation. Since no distinctive marker of dysplastic cells has been recognized, culture of dysplastic epithelial cells would depend on the ability to grossly dissect tissues composed almost entirely of dysplastic epithelia, and this is virtually impossible. Until a method to select live dysplastic cells apart from normal or cancer cells is devised, probably based on the identification of dysplasia-specific cell surface proteins, primary culture of validated populations of dysplastic cells is unlikely. 


\section{Primary adenocarcinomas}

Primary cultures of malignant epithelial cells are typically established from primary adenocarcinomas of the prostate using methodology similar to that used to culture normal cells (for review see Peehl \& Sellers 2002). Because no cancer-specific cell surface antigen has been identified that can be used to sort live cells, establishment of primary cultures of cancer cells depends on precise and detailed histopathological examination of the tissues of origin to exclude the presence of non-malignant epithelial cells. In a number of laboratories, primary cultures have been prepared from well-differentiated cancers (Gleason grade 3) as well as from poorly differentiated cancers (Gleason grades 4 and/or 5). Most investigators avoid establishment of primary cultures from individuals undergoing androgen-deprivation therapy, to avoid unknown effects on cellular biology. The following sections describe the characteristics of cancer-derived primary cultures in comparison with primary cultures from normal tissues and immortal, established cancer cell lines.

\section{Basal vs secretory phenotype of primary cultures from cancer}

A distinctive feature of prostatic adenocarcinomas is the absence of basal epithelial cells. While this is usually simply noted as a histopathological feature, it is interesting to consider whether the absence of basal cells might not in fact be a significant biological component of malignant behavior. A role for basal cells in the regulation and suppression of prostate cancer cells was suggested from work carried out with primary cultures (Miniati et al. 1996). When a prostate cancer cell line was grown on matrix derived from basal-like normal cells, growth was suppressed and the pattern of transcription was altered. It is notable that the basal cell layer becomes attenuated in the premalignant lesion, dysplasia, finally disappearing completely at the point of frank invasion (McNeal et al. 1991). Therefore, the disappearance of the basal layer and its possible tumor suppressive functions may be a prerequisite for initiation of prostate cancer.

On the other hand, the absence of distinctive basal cells in cancer and the many similarities in gene and protein expression between cancer cells and normal secretory epithelial cells have led some to suggest that cancer originates from secretory cells. Among the similarities between normal secretory and cancer cells is the expression of cytokeratins 8 and 18 . However, in primary culture, cells from adenocarcinomas also express cytokeratins 5 and 14 in addition to cytokeratins 8 and 18, like primary cultures from normal tissues, despite the fact that adenocarcinomas themselves do not express these basal cell cytokeratins. The explanation for this unexpected finding may relate to the plasticity of cytokeratin expression. Examples abound of modulation of cytokeratin expression either in vitro or in vivo. For instance, prostatic cells cultured from normal tissues express cytokeratins that are not expressed in prostatic tissues themselves (Sherwood et al. 1989). A particularly illuminating example of plasticity of cytokeratin expression is shown by the behavior of the SV40-immortalized human prostatic cell line, BPH-1. In culture, these cells express only the secretory cell cytokeratins 8 and 18 . Yet when combined with urogenital sinus mesenchyme and grown under the kidney capsule of mice, BPH-1 cells form tumors after hormonal stimulation and express the basal cell cytokeratin 5 (Hayward et al. 2001). It is also noteworthy that even though tumor-derived primary cultures grown on collagen gels had different behavior compared with normal cells, they still expressed basal cytokeratins (Hall et al. 2002).

In fact, while basal cells per se are not present in prostatic adenocarcinomas, certain basal markers, such as CD44, are expressed in some prostate cancers (Liu et al. 2002). Furthermore, an analysis of the expression patterns of 119 cell surface markers (CD antigens) that were previously localized to basal or secretory cells of the normal prostatic epithelium revealed that prostate cancer cell lines expressed more basal-specific than secretory cell-specific molecules (Liu 2000). In addition, van Bokhoven et al. (2003) reported that 7 of 21 established prostate cancer cell lines expressed basal cell cytokeratin 5 . All of the cell lines also expressed cytokeratins 8 and 18. Overall, it appears that attempting to categorize prostate cancer cells as basal or secretory is too simplistic, and in reality a pluripotent phenotype is probably a more accurate description.

Most investigators report that primary cell cultures derived from malignant tissues, like those from normal tissues, do not express AR or PSA (for review see Peehl 2004). While this may be appropriate for normal cultures if they are more like basal cells than fully differentiated secretory cells, this is not typical of cancer cells, which express both AR and PSA in adenocarcinomas (albeit heterogeneously). One interpretation may be that, as for normal cells, standard culture conditions are insufficient to maintain expression of differentiated functions such as expression of AR and PSA. Many established prostate cancer cell lines also do not express AR or PSA; of those that do, 
such as LNCaP, LAPC-4 and MDA PCa 2, AR is commonly mutated (van Bokhoven et al. 2003).

ERs are also expressed by normal and malignant prostatic cells. ER $\alpha$ was expressed by all normal and cancer-derived prostatic epithelial primary cultures analyzed by Pasquali et al. (2001). However, several of the cancer-derived cultures expressed ER $\alpha$ variants, as has been found in established prostate cancer cell lines (Lau et al. 2000). ER $\beta$, expressed by basal epithelial cells in tissues (Leav et al. 2001), was expressed in primary cultures derived from normal tissues (Lau et al. 2000, Pasquali et al. 2001). ER $\beta$ is for the most part absent in prostate cancer tissues, and ER $\beta$ was expressed in only one of six primary cultures of prostate cancer cells (Pasquali et al. 2001). The ER $\beta$ gene promoter is hypermethylated in DU 145 and LNCaP prostate cancer cell lines, preventing expression (Nojima et al. 2001); whether methylation is responsible for lack of expression of ER $\beta$ by primary cultures is unknown. The biological significance of loss of ER $\beta$ from prostatic cancer cells is suggested by the phenotype of ER $\beta$ knock-out mice (Krege et al. 1998). These mice exhibit hyperplasia with aging, suggesting absence of anti-proliferative effects of estrogen or other ligands of ER $\beta$. The role of ER $\beta$ in prostate cancer has been discussed by Signoretti \& Loda (2001).

\section{Cytogenetics}

Chromosomal aberrations in prostate cancer are numerous and complex (Brothman et al. 1999, Paris et al. 2003). This is generally true of established prostate cancer cell lines as well, although karyotypes in the near-diploid, -triploid or -tetraploid are characteristic of a few cell lines (van Bokhoven et al. 2003). In contrast, chromosomal abnormalities in primary cultures derived from prostatic adenocarcinomas have been difficult to detect (for review see Peehl 2004). Primary cultures derived from adenocarcinomas are often diploid by standard karyotypic analyses. Some have interpreted this finding as suggesting that the socalled cancer cultures are in fact comprised of normal cells, either because of misdiagnosis of the tissue of origin or due to outgrowth of normal instead of malignant cells. Indeed, even with the most carefully characterized tissues, it is not possible to rule out the presence of some normal glands within the adenocarcinoma of origin. However, other types of genetic analyses show that cancer-derived cells do in fact have chromosomal changes, albeit at lower frequencies than present in the tumors of origin. As has been suggested, it is quite possible that current culture conditions do not support the survival of the most genetically aberrant cancer cells in vitro.

\section{Proliferation of cancer cells}

In culture, cancer-derived primary cultures of prostatic epithelial cells generally respond similarly to normal cells to growth regulatory molecules, although individual cancer cell cultures that grow independently of EGF or hydrocortisone, or are resistant to growthinhibitory factors such as vitamin $\mathrm{D}$, have been reported (Peehl et al. 1989, Chopra et al. 1996, Gommersall et al. 2004). While dysregulation of signaling pathways involved in growth control is widely observed in prostate cancer cell lines, much less evidence of such dysregulation is seen in primary cultures of cancer cells. This could reflect fewer studies with primary cancer cultures, the inability of primary cultures to reflect the in vivo situation, selection of dysregulation by long-term culture of cell lines, or the fact that most primary cultures are derived from primary adenocarcinomas instead of metastases like the cell lines. Many of the dysregulated proliferation pathways implicated in cancer involve receptor kinases and, as pointed out in a recent review, studies of kinase activation in primary cultures of prostatic epithelial cultures are remarkably few (Maroni et al. 2004). Similarly, studies of phosphatase activity in primary cultures are lacking, although one group reported that the kinase-associated phosphatase $\mathrm{KAP} / \mathrm{Cdil}$ was expressed at low levels in normal prostate tissues and cell cultures, and at high levels in prostate cancer and prostate cancer cell lines (Lee et al. 2000). Repression of $\mathrm{KAP} / \mathrm{Cdil}$ in cancer cells reduced the number of cells in S-phase and reduced tumorigenic potential.

Normal primary cultures were used to demonstrate that overexpression of the co-chaperone protein Cdc37, that targets and activates multiple kinases, drives proliferation, whereas loss of $\mathrm{Cdc} 37$ function arrests growth and leads to apoptosis (Schwarze et al. 2003). This observation is relevant to the development and treatment of prostate cancer, which has elevated levels of Cdc37 compared with normal prostate tissue (Stepanova et al. 2000). In a similar vein, other investigators showed that levels of cyclin D1, which forms a complex with and activates cyclin-dependent kinases to drive the progression through the cell cycle, were low in normal prostatic epithelial cultures compared with prostate cancer cell lines (Han et al. 1998). Perturbations in the cyclins and associated kinases may play a role in dysregulation of growth in cancer.

One growth factor whose levels are significantly increased in prostate cancer compared with normal 
prostatic tissue is IL-6 (Hobisch et al. 2000, Giri et al. 2001), and IL-6 may be elevated in the serum of prostate cancer patients (Michalaki et al. 2004). Giri et al. (2001) found that IL-6 was secreted by normal prostatic cell cultures, at quantities similar to those secreted by some prostate cancer cell lines. Treatment with exogenous IL-6 induced phosphorylation and translocation of Stat-3 into the nucleus. Physiologically relevant concentrations of IL-6 stimulated growth. IL-6 receptors in prostate tissues have been localized by immunohistochemistry mainly to basal epithelial cells in normal tissues, with some staining in secretory epithelial cells and stromal cells as well (Giri et al. 2001). IL-6 receptors in cancer are expressed heterogeneously. Altogether, these findings support the concept that IL-6 acts as an autocrine growth factor in the prostatic epithelium, with increased activity in cancer.

FGF-6 is another mitogenic factor with increased expression in prostate cancer. Expression is low both in normal epithelia in prostatic tissues and in cultured normal cells compared with cancer tissues and cancer cell lines (Ropiquet et al. 2000). Both normal and malignant cells, however, express the receptor for FGF-6 (FGFR-4), and FGF-6 is a potent mitogen for both normal and malignant cells (Ropiquet et al. 2000).

IGF-binding protein (IGFBP)-2 is a major IGFBP in the prostate whose levels are increased in prostate cancer (Cohen et al. 1993). IGFBP-2 suppresses growth of many types of cells, including normal prostatic epithelial cells, but a novel stimulatory effect of IGFBP-2 on prostate cancer cell lines was recently shown (Moore et al. 2003). These findings suggest that elevated expression of IGFBP-2 may have a causal role in progression of prostate cancer.

The human prostate is innervated by the autonomic nervous system and receptors for neurotransmitters, such as muscarinic acetylcholine receptors, have been localized in the prostate. Some investigators have suggested a growth regulatory role for neurotransmitters. Rayford et al. (1997) compared the response to carbachol, an analog of acetylcholine, of primary cultures derived from cancer and non-malignant prostatic tissues and observed a dramatically higher response by the cancer cells. The proliferative effect of carbachol suggests that muscarinic receptors may play a role in prostate cancer growth.

\section{Senescence of cancer cells}

Like cells cultured from normal prostatic tissues, cells from primary adenocarcinomas of the prostate have a finite lifespan in vitro (for review see Peehl 2004). The development of spontaneously established cell lines from primary adenocarcinomas is extremely rare. In fact, van Bokhoven et al. (2003) have shown that almost all of the few such reported lines are in fact derivatives of the common cancer cell lines. Telomerase was reportedly present in primary cultures from cancer (Vicentini et al. 2002) but, as in normal prostatic epithelial cell cultures, expression of telomerase is not associated with an immortal lifespan.

\section{Adhesion, invasion and migration of cancer cells}

The expression of many proteases associated with invasion and migration is increased in prostate cancer, and primary cultures have been used to investigate the biological effects of specific proteases. Among the proteases that have been most studied in primary cultures are matrix metalloproteinases (MMPs). Varani et al. (2001) placed normal prostatic epithelial and stromal cells into culture for 2 days, then evaluated enzymatic activity of MMPs in the conditioned media. They found that stromal cells secreted MMP-2, whereas epithelial cells secreted both MMP-2 and MMP-9. This is somewhat similar to others' findings with serially passaged primary cultures (Wilson et al. 2002), except that basal levels of MMP-2 and MMP-9 were generally undetected in both normal and malignant epithelial cells and only appeared after treatment with TGF $\beta$. Another analysis of primary cultures of normal and malignant cells showed expression of MMP-2, MT1-MMP, MT3-MMP and the tissue inhibitors of MMPs (TIMP)-1 and -2 (Zhang et al. 2002). MMP-7 also was expressed at significant levels in the primary cultures in this study.

Stearns et al. (2003c) found that IL-10 blocked MMP-2 and MT1-MMP transcription and protein synthesis in primary cultures from cancer, and IL-10 also suppressed IGF-I induction of MMP-2 and MT1MMP. IL-10 inhibited the production of MMP-9 by controlling expression of TIMP-1. Primary cultures of cancer cells were used to show that this activity is the result of IL-10 signaling through tyrosine phosphorylation of the IL-10R $\alpha$ chain (Stearns et al. 2003a). The enhancement of IL-10 activity by proteasome inhibitors (Stearns et al. 2003b) suggests potential therapeutic activity of IL-10 in combination with proteasome inhibitors that are currently in clinical trials (Adams et al. 2000).

Primary cultures of epithelial cells from cancer grown in co-culture with bone marrow stromal cells 
made MMP-1 and MMP-7 (Hart et al. 2002). Blocking enzymatic activity of these MMPs with inhibitors reduced the size of colonies formed by the epithelial cells. Other investigators found MMP-7 activity in prostate cancer cell lines, but did not detect expression of MMP-7 in normal primary cultures (Klein et al. 1999, Udayakumar et al. 2001). Expression of MMP-7 in cancer cells appeared to be induced by FGF-1, because when normal cells were transfected with the appropriate receptor and treated with FGF-1, MMP-7 was induced. These investigators concluded that aberrant expression of FGFR-1 in prostate cancer cells mediates induction of MMP-7 expression by FGF-1. It was previously reported by Lang et al. (1998) that both cancer and non-malignant cells invaded bone marrow stromal cells in co-culture similarly, so invasion is not specific to cancer cells.

Hall et al. (2002) found differences in the behavior of normal vs cancer-derived primary cultures in cocultures with stromal cells in type I collagen gels that presumably reflect differential expression of proteases. Stromal cells were seeded in the collagen matrix, then epithelial cells were inoculated on the top of the collagen gel. If the stromal cells were from normal tissue, the normal epithelial cells formed tightly coherent colonies on top of the gel, then migrated into the gel. If the stromal cells were from adenocarcinomas, the normal epithelial cells formed a loosely associated layer of cells on the gel surface. Cancerderived epithelial cells developed an elongated morphology and invaded into gels containing normal stromal cells. On gels with tumor-derived stromal cells, the cancer-derived epithelial cells grew as a monolayer on the gel surface. Contraction of the collagen gels also depended on the particular mix of normal and cancer-derived stromal and epithelial cells. E-cadherin expression was also strikingly different between normal and cancer-derived epithelial cells. It will be of interest to identify the molecular basis of these intriguing phenomena.

Plasminogen activators are reportedly upregulated in prostate cancer. Epithelial cells grown from cancer tissues made urokinase plasminogen activator when co-cultured with bone stromal cells; inhibiting enzymatic activity reduced colony size (Hart et al. 2002). Another study showed that DNA methylation was the underlying molecular mechanism responsible for lack of expression of urokinase plasminogen activator in primary cultures of normal prostatic epithelial cells (Pakneshan et al. 2003).

The generation of eicosanoids by metabolism of arachidonic acid via cyclooxygenase (COX), LOX or other pathways has been implicated in prostate cancer.
Thromboxane synthase converts the COX product, prostaglandin $\mathrm{H}_{2}$, into thromboxane $\mathrm{A}_{2}$. While thromboxane synthase is expressed in some prostate cancer cell lines and tissues and promotes cell motility, normal cultures do not express this enzyme, in line with little or no expression in the epithelium of normal prostatic tissues (Nie et al. 2004).

Hevin, an anti-adhesive extracellular matrix protein that is expressed by cultured normal human prostatic epithelial cells and in the normal prostatic epithelium, is downregulated in metastatic prostate cancer cell lines (Nelson et al. 1998). Similarly, hevin is present in primary adenocarcinomas of the prostate, but not in metastases to the lymph nodes (Nelson et al. 1998). Loss of this molecule is considered to be relevant to the ability of metastatic cells to track through the endothelium. In contrast, normal primary cells weakly express MUC18, a cell adhesion molecule, whereas expression in prostate cancer cell lines is stronger $(\mathrm{Wu}$ et al. 2001).

Annexin II is involved in maintaining calcium homeostasis and regulating the cytoskeleton and cell motility. Several groups reported reduced or lost expression of annexin II in prostate cancer (Chetcuti et al. 2001, Smitherman et al. 2004). Similarly, abundant annexin II was demonstrated in normal cultures, with less or no expression in several prostate cancer cell lines (Liu et al. 2003). Normal cells did not migrate across Boyden chamber membranes, while the cell lines did. Restoration of annexin II to the cancer cells significantly inhibited migration, pointing towards a functional association between loss of annexin II and increased migratory activity of prostate cancer.

Integrins mediate interactions between cells and extracellular matrix proteins. As cell surface receptors, integrins have roles in cell migration, proliferation, and regulation of gene transcription. Alterations of integrins in cancer have been associated with tumor growth, invasion and metastasis. The $\alpha_{v} \beta_{3}$ integrin is expressed by primary cultures of prostate cancer cells but not by normal cells (Zheng et al. 1999). This integrin mediates adhesion to and migration on vitronectin, and stimulation can result in invasion through basement membrane. Because of the specificity of expression of $\alpha_{v} \beta_{3}$ by cancer cells, this integrin may provide a cancer-specific target for therapy. As a first step in this direction, Chatterjee et al. (2001) demonstrated the induction of apoptosis in $\alpha_{v} \beta_{3}$-expressing prostate cancer cell lines but not in $\alpha_{v} \beta_{3}$-negative lung cells by cyclic Arg-Gly-Asp peptides that interfere with the integrin/focal adhesion kinase-mediated signal transduction pathway. 


\section{Steroid hormone metabolism}

Dihydrotestosterone (DHT) is the active form of androgen in the prostate that binds to the AR. The reduction of testosterone to DHT by $5 \alpha$-reductase is therefore a critical step in controlling androgenmediated events in the prostate. The expression and activity of $5 \alpha$-reductase in vitro have mainly been studied in cells cultured from BPH rather than from normal tissues, or in immortalized or established cell lines. Nevertheless, these studies show that one or both isoforms of $5 \alpha$-reductase are expressed by cultured prostatic epithelial cells, whereas $5 \alpha$-reductase type 2 is believed to be the predominant enzyme in the human prostatic epithelium (Berthaut et al. 1996, Delos et al. 1998).

Aldo-keto reductases (AKRs) can convert sex hormones such as androgens, estrogens and progestins into their cognate inactive metabolites or vice versa. Local expression of AKRs in the prostate may control ligand availability at the prereceptor level. AKR1C2 (type $33 \alpha$-hydroxysteroid dehydrogenase) is expressed in the prostate. In primary cultures, high levels of AKR1C2 were found in cancer but not normal cells (Rizner et al. 2003). This finding, together with metabolic studies in prostate cancer cell lines, suggests that in prostate cancer cells, AKR1C2 acts as a 3ketosteroid reductase to eliminate DHT, and thereby reduce activation of the AR. While this seems contradictory with current ideas regarding promotion of prostate cancer progression by DHT, perhaps elimination of DHT from the local tissue milieu by overexpression of AKR1C2 contributes to progression towards androgen-independence.

$17 \beta$-Hydroxysteroid dehydrogenase (17ß-HSD) is another androgen-metabolizing enzyme of interest in the prostate. Type $1017 \beta-H S D$ was shown to catalyze the oxidation of adiol, an almost inactive androgen, to DHT (He et al. 2003). Furthermore, primary cultures of prostate cancer cells had higher levels of $17 \beta-\mathrm{HSD}$ than normal cells. These investigators concluded that $17 \beta$-HSD may play a significant part in non-classic androgen synthesis in the prostate, with higher expression of $17 \beta-H S D$ in cancer cells leading to higher intratumor levels of DHT.

Other androgen-metabolizing enzymes in the prostate include type 5 17ß-HSD and type $13 \beta$-HSD. Expression of both was localized to the basal epithelia of prostate glands, and in one study, both enzymes were found to be expressed by cultured normal prostatic epithelial cells (El-Alfy et al. 1999). However, in another study, 3 $\beta$-HSD was not constitutively expressed in normal cell cultures but was induced by
IL-4 or IL-13 (Gingras \& Simard 1999). The enzyme $3 \beta-H S D$ converts the inactive androgen, dehydroepiandrosterone, to androstenedione (4-dione), and type $517 \beta$-HSD reduces 4 -dione to testosterone. It appears that basal cells may be responsible for local production of testosterone, with conversion to DHT occurring in the AR-positive secretory cells by the action of $5 \alpha$-reductase. The fact that $17 \beta$-HSD is more prominent than $5 \alpha$-reductase in primary cultures of normal prostatic epithelial cells (Delos et al. 1998) presumably reflects a more basal- than secretory-like phenotype of these cells.

As is evident from the previous discussion, steroid hormone metabolism in the prostate is indeed complex, but primary cultures are helping to sort out the many interacting pathways. With the growing recognition of intraprostatic production of active androgens from inactive adrenal precursors, the relevance of these pathways to failure of androgen-ablation therapy to cure prostate cancer is high.

\section{Other metabolic pathways}

The expression of 15-LOX-2, involved in arachidonic acid metabolism, in normal secretory cells of the prostatic epithelium was discussed in a previous section. A pair of donor-matched normal and cancerderived primary cultures was used to study the biological functions of 15-LOX-2 (Tang et al. 2002). Expression was high in the normal cells, as it is in secretory epithelial cells in the prostate. Expression was reduced in the matched cancer culture, and virtually absent in established prostate cancer cell lines, reflecting the downregulation of expression that occurs in prostate cancer tissues (Jack et al. 2000). In the normal cells, 15-LOX-2 expression was inversely correlated with cell cycle progression, consistent with its expression in non-proliferative secretory cells in the prostate. To gain information about the biological functions of 15-LOX-2, the effect of its metabolic product, 15(S)HETE, on cellular proliferation and survival was monitored. Cancer cells were more sensitive to growth inhibitory and apoptotic effects of 15(S)-HETE, and restoration of 15-LOX-2 expression to prostate cancer cell lines induced cell cycle arrest. Overall, these data suggest that 15 -LOX-2 is a negative cell regulator in the normal prostatic epithelium whose loss is advantageous to prostate cancer development.

The cytochrome P450-dependent monooxygenases CYP1A1 and CYP1A2 are phase 1 metabolic enzymes that are relevant to carcinogenesis. CYP1A1 was found to be inducible in both normal and cancer-derived primary cultures, as is typical of cells of adult tissues 
(Sterling \& Cutroneo 2004). CYP1A2 expression was absent but inducible in cancer cells, and was constitutively expressed in normal cells. These primary cultures should therefore provide a good model system for investigation of the molecular mechanisms of prostate cancer development and progression from metabolic activation of dietary and environmental carcinogens.

\section{Angiogenesis}

The ability to stimulate new blood vessel formation (angiogenesis) is critical to cancer progression. Primary cultures have been used to investigate processes relevant to physiological and pathological angiogenesis. Thrombospondin-1 (TSP-1) is an anti-angiogenic factor that is secreted in substantial quantities by cultured normal human prostatic epithelial cells (Doll et al. 2001). However, pro-angiogenic factors, including vascular endothelial growth factor (VEGF) and FGF-2, are also secreted by normal cells (Campbell et al. 1999, Doll et al. 2001). In short-term (2 day) cultures, TSP-1 outweighed VEGF/FGF-2 production and resulted in net anti-angiogenic activity. In serially passaged cultures, the balance shifted and the secretions became angiogenic. Short-term cultures derived from cancers were also angiogenic, mainly due to increased VEGF and FGF-2 and decreased TSP-1. Other angiogenic factors that were expressed inconsistently by normal and/or cancer-derived primary cultures included IL-8, GRO $\alpha$, HGF, and TGF $\beta$ (Doll et al. 2001). IGF-I increased secretion of VEGF by normal cells, dependent on phosphatidylinositol 3kinase and MEK1/2 signaling pathways (Burroughs et al. 2003). IGF-I also increased expression of hypoxia-inducible factor-1 (HIF-1), but studies with prostate cancer cell lines suggested that an additional signal that is not stimulated by IGF-I in normal cells is needed for HIF-1 to stimulate transcription from the VEGF hypoxia response element in cancer cells. Indeed, another study showed that HIF-1 transcriptional regulation was low in normal prostatic epithelial cell cultures and increased in prostate cancer cell lines in association with increasing metastatic ability (Salnikow et al. 2000). High inducibility of HIF-1dependent genes may be part of the reason for survival of aggressive cancer cells in hypoxic conditions.

Hyaluronidase is an enzyme that degrades the glycosaminoglycan, hyaluronan, into small fragments. Hyaluronan and its degradation products have been found to have biological properties consistent with tumor-promoting abilities, including promotion of cell migration and angiogenesis. Both hyaluronidase and hyaluronan were found to be increased in prostate cancer compared with normal tissues (Lokeshwar et al. 2001), and recently, HYAL1 type hyaluronidase was shown to be an independent prognostic marker (Posey et al. 2003). When primary cultures of epithelial cells were examined, cancer-derived cells were noted to secrete higher amounts of both the enzyme and the glycosaminoglycan than cells from normal tissues (Lokeshwar et al. 2001). Furthermore, the pattern of higher expression of these tumor markers in cancers of higher Gleason grades was mimicked in cell cultures derived from high vs low grades. Primary cultures may serve as a useful model to further investigate the role of hyaluronidase-generated fragments of hyaluronan in cancer progression. The role of hyaluronan in tumor growth was highlighted by the impairment of growth and vascularization of a prostate cancer xenograft model when synthesis of hyaluronan was blocked (Simpson et al. 2002). Similarly, overexpression of HYAL1 in an orthotopic model of prostate cancer resulted in significantly increased numbers of metastases (Patel et al. 2002).

In another study, six of six cancer-derived primary cultures where found to have increased expression of inducible nitric oxide synthase (iNOS) mRNA compared with the paired non-neoplastic primary cultures (Wang $\mathbf{J}$ et al. 2003). It has been shown that increased levels of nitric oxide, produced by iNOS, can contribute to angiogenesis, growth and metastasis, and immune suppression. In this same study, the investigators also showed that iNOS protein levels were significantly higher in immunostained prostate cancer tissue sections than in adjacent benign epithelia.

\section{Gene expression}

Gene expression profiling and proteomics are providing novel insights into cancer-related traits. Comparisons of genetic expression profiles of prostatic adenocarcinomas with either normal tissues or BPH have been published by a number of groups (for review see De Marzo et al. 2004). Genetic profiling of prostate cancer cell lines in comparison with prostate cancer tissues has been performed by several investigators. It is interesting to note that Welsh et al. (2001) found only a small number of genes with concordant expression in established prostate cancer cell lines and malignant prostate tissues, and Bull et al. (2001) found that cell lines overexpressed fewer genes than did cancer tissues in comparison with normal tissues. Nevertheless, Dhanasekaran et al. (2001) found that cell lines clustered with malignant rather than with normal or benign tissues in microarray analyses. 
While it seems that no similar analyses of primary cultures of prostate cancer cells in comparison with tissues have yet been reported, the genetic expression profile of cultured normal prostatic cells was compared with profiles of five xenograft-derived prostate cancer cell lines. A consensus class of genes that differed in all of the lines relative to the normal cells was identified (Glinsky et al. 2004). Many of these genes were similarly differentially expressed in prostate cancer tissues compared with normal tissues, indicating that these genes may indeed be relevant to prostate cancer.

One gene found to be overexpressed in prostate cancer compared with non-malignant tissues by cDNA microarray analysis was LIM kinase 1 (LIMK1) (Dhanasekaran et al. 2001). In vitro studies confirmed the lower expression of this kinase in normal prostatic epithelial cells compared with many prostate cancer cell lines (Davila et al. 2003). These studies also showed that reducing the expression of LIMK1, which is involved in reorganization of the actin cytoskeleton, abolished the invasiveness of cancer cells. A role for LIMK1 in mediating the invasive property of prostate cancer is therefore implicated, and LIMK1 may be a new therapeutic target.

Aberrant DNA methylation patterns are posited to be some of the earliest genomic changes in prostate cancer, and indeed, the frequency of hypermethylation of $\mathrm{CpG}$ islands was high in prostate cancer cell lines compared with normal cells (Yegnasubramanian et al. 2004). Hypermethylation of a select set of genes was shown to distinguish benign prostatic tissues from primary adenocarcinomas in this study.

Das et al. (2001) compared the expression pattern of fatty acid-binding proteins (FABPs) in cultured normal prostatic epithelial cells and prostate cancer cell lines. Interestingly, the elevation of L-FABP and IFABP, and the downregulation of A-FABP and EFABP, that were seen in the cancer cell lines compared with the normal cells were also noted in normal vs malignant prostatic tissues. Furthermore, B-FABP was elevated in only one of the cancer cell lines, LNCaP, considered to be more well-differentiated than other prostate cancer cell lines, and B-FABP was distinctively elevated only in well-differentiated prostate cancers compared with normal epithelium or poorly differentiated cancers. These results suggest that the normal primary cultures and cancer cell lines faithfully replicate the in vivo situation and will be useful models for further investigation of the role of FABPs in prostatic carcinogenesis.

Another gene, EBAG9/RCAS1, was found to be highly expressed in prostate cancer cell lines compared with normal cells (Takahashi et al. 2003). The protein product of this gene is a cancer cell surface antigen implicated in immune escape. Besides the implications of overexpression of this gene in cancer progression, localization of the protein on the cell surface makes EBAG9/RCAS1 a potential target for antibodymediated therapy or for selection of cancer cells for experimental purposes.

\section{Metastatic prostate cancer cells}

No method has been devised for reproducible primary culture of prostatic cancer cells from bony or soft tissue metastases. The small number of immortal metastatic cancer cell lines that exist represent rare successes from hundreds of attempts to establish such lines. There are a few reports of short-term cultures in which epithelial cells were isolated from bone marrow aspirates and expanded somewhat in culture (Pantel et al. 1995). One group purportedly established prostatic primary cultures from a number of metastatic sites and investigated expression of $\beta-2$ microglobulin as a marker of metastatic disease, but little information was provided about the culture methodology or characterization of the cultures (Abdul \& Hoosein 2000). However, in a recent study of the proliferative potential of occult metastatic cells in bone marrow of patients with solid epithelial tumors, 46 patients with prostate cancer were included (Solakoglu et al. 2002). Bone marrow cells were plated on extracellular matrix and the number of cytokeratin-positive (epithelial) cells was determined at each passage. Cytokeratin-positive cells were seen in cytospin preparations of the bone marrow aspirates in $24 \%$ of the prostate cancer patients; after culture, this percentage rose to $94 \%$ of the attached cell population. In fact, the highest median number of in vitro-expanded, cytokeratinpositive cells was obtained from prostate cancer patients in comparison with individuals with other types of tumors. In a previous study using similar methodology but including transfection with the SV40 $\mathrm{T}$-Ag to create immortal cell lines, it is interesting to note that cells not expressing the T-Ag did not survive after crisis (Putz et al. 1999). This phenomenon emphasizes the point that immortality is not necessarily an intrinsic feature even of metastatic cells. Further development of the methodology described in these publications may lead to enhanced ability to capture and study metastatic prostatic epithelial cells in vitro.

\section{Preclinical studies with primary cultures}

While the cell in which cancer originates in the normal epithelium (stem, basal, transit amplifying or secretory) 
remains unknown, and primary cultures may include a variable mixture of these diverse phenotypes, primary cultures derived from normal tissues have been used to study numerous aspects of normal prostatic biology relevant to carcinogenesis and chemoprevention. Primary cultures of normal prostatic epithelial cells are often compared with established prostate cancer cell lines to generate evidence of cancer-specific traits. When normal cultures are compared with established cell lines, many differences indeed are seen. However, it is difficult to know whether observed differences really represent differences between normal and malignant cells, or simply reflect the different culture conditions in which the primary cultures vs the cell lines are generally maintained. The most informative studies are those in which donor-matched neoplastic and nonneoplastic primary cultures of prostate cells are compared, because these are grown under identical conditions and inter-individual variation among donors is controlled. Barring the availability of donor-matched pairs, primary cultures of normal and cancer cells from different individuals are still valuable because at least they are grown in identical culture conditions. Features that have been reported to differ between primary cultures derived from adenocarcinomas vs normal tissues are listed in Table 5. Another advantage of primary cultures is that the generality of a given observation can be confirmed by studying cell cultures derived from numerous individuals, and cancer cultures can be derived from adenocarcinomas representing a range of aggressiveness. In the following sections, preclinical studies with primary cultures that are relevant to clinical application are discussed.

\section{Chemoprevention}

Ideally, a chemopreventive agent might kill cancer cells as they arise while having minimal or no effect on normal cells. Gupta et al. (2001) used normal primary cultures and established cancer cell lines to show that apigenin, a flavonoid that is abundant in fruits and vegetables, may exhibit this type of differential activity. While apigenin had moderate growth-inhibitory activity on normal cells, cancer cells underwent apoptosis when treated with apigenin. Similarly, the Bowman-Birk inhibitor, a soybean-derived serine protease inhibitor with demonstrated anti-cancer activity both in vitro and in vivo, was found to inhibit the growth of several prostate cancer cell lines but not normal prostatic epithelial cells (Kennedy \& Wan 2002). Allyl isothiocyanate, a constituent of cruciferous vegetables, caused $\mathrm{G}_{2} / \mathrm{M}$ arrest and induced apoptosis in several prostate cancer cell lines, while minimally affecting the survival of normal prostatic epithelial cells (Xiao et al. 2003).

Tomato, soy and tea polyphenols (genistein, quercetin, biochanin $\mathrm{A}$, daidzein and others) have been proposed as chemopreventive agents. Polyphenols inhibited the growth of normal prostatic epithelial cells (Hedlund et al. 2003), with inhibition of the IGF-I signal transduction pathway implicated in this activity (Klein \& Fischer 2002, Wang S et al. 2003). These findings provide further support for potential chemopreventive activity of polyphenols because IGF-I activity has been linked to increased prostate cancer risk (Pollak et al. 2004). In many cases, the growth inhibitory concentrations of these compounds were within the range that can be attained through dietary consumption (Hedlund et al. 2003). In contrast, prostate cancer cell lines show variable responses to polyphenols, and in many cases require supraphysiological concentrations for maximal effect (Hedlund et al. 2003).

The effects of vitamin D compounds on prostate cells are also consistent with chemopreventive activity (for review see Krishnan et al. 2003). While vitamin D does not exhibit preferential activity on prostate cancer vs normal cells, vitamin $\mathrm{D}$ inhibits growth and increases differentiation of primary cultures derived from normal and malignant tissues and cancer cell lines. Epidemiological data link low levels of vitamin D to increased risk of prostate cancer. An important discovery was the finding that normal prostatic epithelial cells themselves express the enzyme, vitamin D 1 $\alpha$-hydroxylase (CYP27B1), that synthesizes the active metabolite of vitamin $\mathrm{D}, 1,25$-dihydroxyvitamin $\mathrm{D}_{3}$. This finding implies that local production of 1,25 dihydroxyvitamin $\mathrm{D}_{3}$ is biologically significant. Furthermore, the finding that primary cultures of prostate cancer cells and prostate cancer cell lines are deficient in CYP27B1 suggests that elimination of local production of vitamin D may play a role in prostatic carcinogenesis. Chemopreventive strategies might be focused on restoring or compensating for loss of local synthesis of active vitamin $\mathrm{D}$ in the premalignant or early stages of prostatic cancer development.

Retinoids also modulate growth and differentiation of prostatic epithelial cells and various retinoids have been tested for chemopreventive and/or chemotherapeutic activity against prostate cancer (for review see Peehl \& Feldman 2003). Primary cultures have been used to study retinoid metabolism, with some thoughtprovoking findings. Lecithin:retinol acyltransferase (LRAT) is an enzyme that metabolizes retinol to retinyl esters, the primary intracellular storage form of 
Table 5 Features that distinguish primary cultures of epithelial cells derived from adenocarcinomas vs normal tissues

\begin{tabular}{|c|c|}
\hline Feature & Reference \\
\hline $\mathrm{ER} \alpha$ variants & Lau et al. (2000) \\
\hline $\mathrm{ER} \beta$ & Pasquali et al. (2001) \\
\hline Cytogenetics & Reviewed in Peehl (2004) \\
\hline Growth factor independence & $\begin{array}{l}\text { Peehl et al. (1989), } \\
\text { Chopra et al. (1996) }\end{array}$ \\
\hline $\begin{array}{l}\text { Resistance to growth } \\
\text { inhibitory factors }\end{array}$ & Gommersall et al. (2004) \\
\hline $\begin{array}{l}\text { Response to acetyl } \\
\text { choline analog }\end{array}$ & Rayford et al. (1997) \\
\hline Behavior in collagen gels & Hall et al. (2002) \\
\hline$\alpha_{v} \beta_{3}$ integrin & Zheng et al. (1999) \\
\hline AKR1C2 & Rizner et al. (2003) \\
\hline Type $1017 \beta-H S D$ & He et al. (2003) \\
\hline $15-L O X-2$ & Tang et al. (2002) \\
\hline CYP1A2 & Sterling \& Cutroneo (2004) \\
\hline HYAL1 & Lokeshwar et al. (2001) \\
\hline iNOS & Wang J et al. (2003) \\
\hline LRAT & Guo et al. (2002) \\
\hline Vitamin D $1 \alpha(\mathrm{OH})$ ase & Hsu et al. (2000) \\
\hline SSTR1/SSTR2 & Sinisi et al. (1997) \\
\hline NMR spectra & Yacoe et al. (1991) \\
\hline Hyaluronan & Lokeshwar et al. (2001) \\
\hline
\end{tabular}

vitamin A. Retinol esterification occurred normally in primary cultures of prostatic epithelial cells from normal tissues (Lewis \& Hochadel 1999, Guo et al. 2002). Correspondingly, LRAT mRNA transcripts were present in these cells. In comparison, LRAT mRNA was considerably reduced in both primary cultures derived from prostatic adenocarcinomas and in prostate cancer cell lines and conversion of retinol to retinyl esters was markedly reduced (Guo et al. 2002). These findings imply that prostate cancer cells are retinoid-deficient relative to normal cells, implicating aberrant retinoid metabolism in the process of prostatic carcinogenesis. It is noteworthy that two enzymes, CYP27B1 and LRAT, involved in creating active metabolites of the potent growth-suppressing and differentiation-promoting vitamins $\mathrm{A}$ and $\mathrm{D}$, are aberrant in prostate cancer cells, both in primary culture and in established cell lines. Furthermore, these deficiencies were noted even in primary cultures derived from well-differentiated cancers (Gleason grade 3 ), implying that these are early steps in prostate cancer development. As suggested in reference to loss of the ability of prostate cancer cells to synthesize the active metabolite of vitamin $\mathrm{D}$, strategies to restore or compensate for loss of LRAT activity may be a new chemopreventive mechanism.

Somewhat surprisingly, antagonists of retinoic acid receptors were reportedly potent growth inhibitors of primary cultures of prostate cancer cells as well as of cancer cell lines (Hammond et al. 2001). While no mechanistic explanation for this unexpected finding was presented, it is possible that this result relates to the apparent growth stimulatory effect of low concentrations of retinoic acid that have been observed in primary cultures of prostatic epithelial cells (Peehl et al. 1993).

Consumption of lycopene, a red carotenoid obtained primarily from tomatoes, has been inversely correlated with risk of prostate cancer (Etminan et al. 2004). In studies with primary cultures of normal prostatic epithelial cells, lycopene was found to inhibit proliferation and block cell cycle progression at physiologically relevant concentrations (Obermuller-Jevic et al. 2003).

Primary cultures have also been used to explore potential interactions between putative chemopreventive agents. Synergistic growth inhibition of normal prostate cells by vitamin D and genistein was shown (Rao et al. 2002), raising the possibility of dietary supplementation with vitamin D and genistein as an effective prostate cancer prevention strategy. Retinoic acid and vitamin D also synergistically inhibit the growth of primary cultures of prostatic epithelial cells, both normal and malignant (Peehl et al. 1995).

Some epidemiological studies have also linked consumption of non-steroidal anti-inflammatory drugs (NSAIDs) with lower risk of prostate cancer (Mahmud et al. 2004). The basis of this effect is believed to be inhibition of COX-2, which synthesizes prostaglandins that stimulate the growth of prostate cancer. The pattern of expression of COX-2 in human prostate tissues is variable in different reports, as is expression in cultured cells. Some groups reported that cultured normal prostatic epithelial cells express high levels of this enzyme (Lim et al. 1999, Subbarayan et al. 2001), whereas others found low expression (Hsu et al. 2000). NSAIDs may exert chemopreventive activity by lowering the production of mitogenic prostaglandins in the prostatic epithelium.

In a previous section, the attenuated activation of the tumor suppressor p53 in normal prostatic epithelial cells in response to DNA damage was discussed. Given the anti-cancer functions of $\mathrm{p} 53$, restoration of $\mathrm{p} 53$ activity might be a viable chemoprevention strategy. That this may be feasible was demonstrated by the upregulation and activation of $\mathrm{p} 53$ in normal prostatic epithelial cells by leptomycin $\mathrm{B}$, an antifungal agent that inhibits protein export from the nucleus to the cytoplasm and thus prevents the proteasomal degradation of p53 (Lecane et al. 2003). While leptomycin B is too toxic for clinical use, new proteasomal inhibitors 
that are in clinical trials to treat cancer (Adams et al. 2000) may achieve the same effect on p53 and find a use in chemoprevention as well as chemotherapy. Another compound that causes significant upregulation of $\mathrm{p} 53$ in primary cultures of either normal or malignant prostatic epithelial cells is triptolide (Kiviharju et al. 2002). A natural product in Phase I clinical trials, triptolide at low concentrations induces senescence and, at high concentrations, causes apoptosis of prostatic epithelial cells. These dose-dependent effects might be taken advantage of in designing chemopreventive vs chemotherapeutic strategies with this compound.

\section{Chemotherapy}

Screening experimental chemotherapeutic drugs has largely been accomplished with prostate cancer cell lines, although in the early 1990s a large National Cancer Institute-sponsored screen of synthetic and natural products was carried out with primary cultures of prostate cancer cells derived from adenocarcinomas of differing Gleason histopathological patterns (Peehl et al. 1994a). It is felt that the rapid proliferative rate of many of the prostate cancer cell lines leads to inappropriate selection of drugs with anti-proliferative activity, which might not exhibit much efficacy on generally slowly growing prostatic adenocarcinomas. Primary cultures may prove to be a more realistic model.

Apoptosis is a critical factor balancing proliferation in normal epithelium and maintaining tissue homeostasis. The rate of apoptosis is decreased in malignant epithelium (Berges et al. 1995). Restoring apoptosis is a therapeutic strategy, and requires an understanding of mechanisms of apoptosis in prostatic epithelial cells (Isaacs 2000). Thapsigargin, a sesquiterpene lactone that selectively inhibits the sarcoplasmic reticulum/ endoplasmic reticulum calcium-dependent ATPase, induced apoptosis in primary cultures of cancer cells (Lin et al. 1997). An important feature of this study was that the cancer cells were made quiescent by maintaining at confluency in thymidine-free medium. This state more closely mimics that of cancer in vivo, which typically has a low proliferative index, than that of cells in standard culture media that are rapidly proliferating. The low proliferation rate of most prostate cancers requires proliferation-independent cytotoxic therapies such as provided by thapsigargin.

Coffey et al. (2001) used primary cultures of normal and cancer-derived cells to investigate molecular mechanisms of apoptosis. Their study was based on their preliminary findings that procaspase- 3 levels were decreased in prostate cancer tissues. Since activation of caspases is often essential for apoptosis, lack of caspases could have a detrimental effect on efficacy of apoptosis-inducing therapies. Coffey et al. found that pretreatment with diethyl-maleate (DEM) prior to exposure to Fas antibody, etoposide or radiation increased sensitivity to induction of apoptosis by these agents. This effect was attributed to DEM's depletion of cytoplasmic levels of glutathione, which protects cells from oxidative damage. Increased procaspase-3 and caspase- 8 were also associated with DEM treatment. Such studies are relevant to the development of strategies to sensitize prostate cancer to chemical or radiation therapy.

Recent findings suggest that quinazoline-based $\alpha_{1}$-adrenoceptor antagonists, already in clinical use for the treatment of $\mathrm{BPH}$, may have potential for therapy of prostate cancer as well. These antagonists induce apoptosis in prostate cancer cell lines via an unidentified but $\alpha_{1}$-adrenoceptor-independent mechanism (Benning \& Kyprianou 2002). Of significance is the observation that normal prostatic epithelial cells, in comparison with the cancer cell lines, are very resistant to the apoptotic effects of the antagonists (Benning \& Kyprianou 2002). The apparent selective activity of these drugs on cancer cells is clearly a desirable feature. Thebault et al. (2003) showed that $\alpha_{1}$ adrenergic receptor-stimulated signaling in normal prostate cells is preferentially coupled to storeindependent transient receptor potential (TRP) channels, as opposed to store-operated TRP channels in the prostate cancer cell line LNCaP. It should be noted, however, that other investigators found no evidence for functional $\alpha_{1}$-adrenergic receptors in cultured normal prostatic epithelial cells, in line with the apparent absence of these receptors in epithelia of prostatic tissues (Kanagawa et al. 2003, Marinese et al. 2003). Nevertheless, these investigators suggest that isoform-specific inhibitors of TRP channels may be useful for treating prostate cancer.

In another study, treatment with neutral endopeptidase (NEP) was found to increase protein kinase $C-\delta$ in PC-3 but not normal prostate cells, and to preferentially sensitize PC-3 cells to etoposide-induced apoptosis, implying that NEP might augment chemosensitivity in prostate cancer with minimal toxicity in normal tissues (Sumitomo et al. 2004).

Selenium has been primarily investigated for chemoprevention of prostate cancer, but new data suggest that selenium may also be useful for treatment. Ghosh (2004) demonstrated that normal prostatic epithelial cells were markedly resistant to the apoptotic-inducing properties of sodium selenite, whereas prostate cancer 
cell lines were very sensitive. This differential sensitivity between normal and cancer cells to selenite was hypothesized to be linked to different metabolism of arachidonic acid.

Like selenium, vitamin $\mathrm{D}$ compounds are being considered both to prevent (discussed above) and treat prostate cancer (for review see Krishnan et al. 2003). Hypercalcemia caused by treatment with the active metabolite, 1,25-dihydroxyvitamin $\mathrm{D}_{3}$, is being circumvented in a variety of ways, including novel dosing regimes, use of analogs, and combination therapy with other drugs. Results from studies with primary cultures of cancer cells suggest that combination therapy of 1,25-dihydroxyvitamin $\mathrm{D}_{3}$ with ketoconazole, an inhibitor of P450 enzymes used for second-line androgen-ablation therapy, may be a useful clinical strategy (Peehl et al. 2002). Ketoconazole simultaneously blocks androgen production while inhibiting metabolism of 1,25-dihydroxyvitamin $\mathrm{D}_{3}$, and has other growth-inhibitory effects on prostate cancer cells independently of these two activities.

The EGF receptor tyrosine kinase inhibitor ZD1839 has shown encouraging activity in clinical trials against a variety of cancers. Primary cultures derived from prostate cancers were used to demonstrate that EGF receptors were present and phosphorylated, and that ZD1839 reduced receptor auto- and EGF-induced phosphorylation in conjunction with inhibition of cell growth (Vicentini et al. 2003). These results suggest that ZD1839 may have potential for treating prostate cancer.

Based on the observation that p53 is non-functional in primary cultures of prostate epithelial cells (discussed in a previous section) and often mutated in established prostate cancer cell lines (van Bokhoven et al. 2003) and prostatic adenocarcinomas (Downing et al. 2001), drugs that induce apoptosis by p53independent mechanisms might be more active than those that require p53 activity. Brefeldin $\mathrm{A}$ is one such compound, and it is a potent inducer of apoptosis in primary cultures of cancer cells (Wallen et al. 2000).

Analogs of somatostatin have been tested in clinical trials against prostate cancer, with limited efficacy. Results from studies by Sinisi et al. (1997) with primary cultures provide a possible explanation for these less than promising clinical results. These investigators characterized the somatostatin receptor subtypes in primary cultures from normal and malignant prostatic tissues, and observed that the subtype SSTR1 was expressed only in cancer cells while SSTR2 was found only in normal cells. The use of SSTR2-selective analogs in the clinical trials, therefore, presumably targeted the wrong cell population, and better efficacy might be achieved with SSTR1-selective analogs.

Ideas for new therapeutic strategies are taking advantage of novel information derived from genetic profiling of normal vs malignant tissues. One gene found overexpressed in prostate cancer, particularly androgen-independent cancer, was fatty acid synthase (FAS). This enzyme converts dietary carbohydrate or protein to fat. The resistance of normal prostatic cells to the growth-inhibitory and apoptosis-inducing effects of the FAS inhibitor, cerulenin, compared with prostate cancer cell lines suggests that FAS may serve as a target for antimetabolite therapy in prostate cancer (Pizer et al. 2001).

\section{Cytotoxin therapy}

Cytotoxins composed of tumor-selective cytokines coupled to a toxin moiety are a new class of molecular targeting agents. On the basis of studies with primary cultures and established prostate cancer cell lines, Husain et al. (2003) proposed that administration of IL-4 fused with Pseudomonas exotoxin (IL4-CTx) may provide an effective therapy for prostate cancer. These investigators demonstrated that IL-4 receptors are present in prostate cancer tissues as well as on primary cultures and cell lines, and that all of the cultured cells were very sensitive to IL4-CTx cytotoxicity. IL4-CTx caused regression of xenografts of several of the prostate cancer cell lines, demonstrating pre-clinical efficacy of this approach.

\section{Radiation therapy}

Given that radiotherapy is a widely used treatment option for men with prostate cancer, it is surprising that relatively little has been done to investigate radiation sensitivity and response of primary cultures. Bromfield et al. (2003) measured clonogenic survival and apoptosis of primary cultures of irradiated normal prostatic epithelial cells, but the responses of the normal cells were compared with those of established prostate cancer cell lines rather than to primary cultures of cancer cells. However, normal cells were more sensitive than the cancer cell lines, suggesting radioresistance of the latter.

In another study, Dunlap et al. (2003) determined the sensitivity of primary cultures of cancer-derived cells to ionizing radiation, then showed that pretreatment with vitamin D potentiated the growthinhibitory effect of radiation. They used normal prostatic stromal cells to show that the normal cells were substantially more resistant to combined treatment than prostate cancer cells. Thus, vitamin D might 
be a biological response modifier that could permit a reduction in the dose of radiation used to treat prostate cancer and reduce treatment-related morbidity.

\section{Gene therapy}

Primary cultures of prostate cancer cells were used to test the effects of a recombinant adenovirus vector expressing wild type p53 (Asgari et al. 1997). The primary cultures were growth-inhibited, as was the growth of a xenograft of the DU 145 prostate cancer cell line, showing preclinical activity of this gene therapy approach. Another group showed that complexing adenovirus-based plasmids to cationic liposomes led to high levels of gene transfer and expression in primary cultures of epithelial cells derived from prostatic adenocarcinomas (Vieweg et al. 1995).

The cytokine IL-24, when expressed by a replicationincompetent adenovirus (Ad.mda-7), shows broad specificity for apoptotic effects on cancer cells vs normal cells. Results of studies with normal prostatic epithelial cells and prostate cancer cell lines reiterated this general theme, with growth suppression and apoptosis induced by Ad.mda-7 evident only in the cancer cells, despite similar kinetics of infection and expression of IL-24 in both the normal and cancer cells (Lebedeva et al. 2003).

\section{Imaging}

Non-invasive imaging technologies are being developed to obtain reliable markers for diagnosis of prostate cancer. One of the technologies that shows promise is proton magnetic resonance spectroscopic imaging $\left({ }^{1} \mathrm{H}\right.$ MRSI). ${ }^{1} \mathrm{H}$ MRSI spectra in prostate cancer tissues typically exhibit low levels of citrate and increased levels of total choline (consisting of phosphocholine, glycerophosphocholine and free choline). Similarly, ${ }^{1} \mathrm{H}$ MRSI spectra of normal prostatic epithelial cell cultures and prostate cancer cell lines revealed elevated levels of phosphocholine and glycerophosphocholine in the cancer cells (Ackerstaff et al. 2001). Effects of cell density, doubling time or other culture conditions as a factor in this differential phenotype between the primary cultures and cell lines were ruled out, suggesting that the differences are in fact attributable to alterations of phospholipid metabolism in cancer. An earlier investigation of ${ }^{1} \mathrm{H}$ NMR spectra in primary cultures of prostate cancer compared with normal cells also suggested that cancer cells had smaller amounts of citrate than normal cells (Yacoe et al. 1991). These in vitro studies support further investigation of the choline signal as an imaging marker to detect malignant prostate cells for diagnosis and treatment.

\section{Conclusions}

The contribution of primary cultures to our knowledge of normal and malignant prostate biology has perhaps been under-appreciated. Challenges that remain in order for primary cultures to be fully utilized as in vitro models include the isolation, culture and characterization of stem cells, and development of methods that induce or maintain the fully differentiated secretory epithelial cell phenotype, include robust androgen responsiveness.

The many emerging cancer-related traits expressed by primary cultures derived from adenocarcinomas emphasize the value of this model system in the repertoire of tools for prostate cancer research. However, the changing nature of prostate cancer at diagnosis will have a significant impact on our ability to establish primary cultures from adenocarcinomas unless some new tools are developed. Twenty years ago, the mean volume of primary adenocarcinomas of the prostate diagnosed at Stanford was $5.3 \mathrm{cc}$ (Stamey et al. 2004). Even given that relatively large tumor size, gross dissection of malignant tissues for culture was difficult, and in my personal experience, subsequent histopathological analysis showed that even our expert pathologist had accessed tissues composed of $>90 \%$ cancer only about half of the time. Now, the mean volume of cancers at diagnosis is $2.4 \mathrm{cc}$. Correspondingly, our success rate at grossly dissecting tissues that are mostly cancer has significantly dropped. Unless a cell surface marker that can reliably sort live cancer from non-malignant cells is identified soon, primary cultures derived from prostatic adenocarcinomas will become a scarce commodity. I feel that this will be a great loss to the research community, considering the unique information that has been and could be gained from such cultures.

\section{References}

Abdul M \& Hoosein N 2000 Changes in beta-2 microglobulin expression in prostate cancer. Urologic Oncology 5 168-172.

Abrahamsson PA 1999 Neuroendocrine differentiation in prostatic carcinoma. Prostate 39 135-148.

Ackerstaff E, Pflug BR, Nelson JB \& Bhujwalla ZM 2001 Detection of increased choline compounds with proton nuclear magnetic resonance spectroscopy subsequent to malignant transformation of human prostatic epithelial cells. Cancer Research 61 3599-3603. 
Adam RM, Borer JG, Williams J, Eastham JA, Loughlin KR \& Freeman MR 1999 Amphiregulin is coordinately expressed with heparin-binding epidermal growth factor-like growth factor in the interstitial smooth muscle of the human prostate. Endocrinology 140 5866-5875.

Adams J, Palombella VJ \& Elliott PJ 2000 Proteasome inhibition: a new strategy in cancer treatment.

Investigational New Drugs 18 109-121.

Asgari K, Sesterhenn IA, McLeod DG, Cowan K, Moul JW, Seth P \& Srivastava S 1997 Inhibition of the growth of pre-established subcutaneous tumor nodules of human prostate cancer cells by single injection of the recombinant adenovirus p53 expression vector. International Journal of Cancer 71 377-382.

Balint EE \& Vousden KH 2001 Activation and activities of the p53 tumour suppressor protein. British Journal of Cancer 85 1813-1823.

Belair CD, Yeager TR, Lopez PM \& Reznikoff CA 1997 Telomerase activity: a biomarker of cell proliferation, not malignant transformation. PNAS 94 13677-13682.

Benning CM \& Kyprianou N 2002 Quinazoline-derived alpha1-adrenoceptor antagonists induce prostate cancer cell apoptosis via an alpha1-adrenoceptor-independent action. Cancer Research 62 597-602.

Berges RR, Vukanovic J, Epstein JI, Carmichel M, Cisek L, Johnson DE, Veltri RW, Walsh PC \& Isaacs JT 1995 Implication of cell kinetic changes during the progression of human prostatic cancer. Clinical Cancer Research 1 473-480.

Berns A 2002 Senescence: a companion in chemotherapy? Cancer Cell 1 309-311.

Berthaut I, Portois MC, Cussenot O \& Mowszowicz I 1996 Human prostatic cells in culture: different testosterone metabolic profile in epithelial cells and fibroblasts from normal or hyperplastic prostates. Journal of Steroid Biochemistry and Molecular Biology 58 235-242.

Bettendorf O, Heine B, Kneif S, Eltze E, Semjonow A, Herbst H, Stein H, Bocker W \& Poremba C 2003 Expression-patterns of the RNA component (hTR) and the catalytic subunit (hTERT) of human telomerase in nonneoplastic prostate tissue, prostatic intraepithelial neoplasia, and prostate cancer. Prostate 55 99-104.

Bonkhoff H 1998 Neuroendocrine cells in benign and malignant prostate tissue: morphogenesis, proliferation, and androgen receptor status. Prostate. Supplement $\mathbf{8}$ $18-22$.

Bonkhoff H, Stein U \& Remberger K 1994 Multidirectional differentiation in the normal, hyperplastic, and neoplastic human prostate: simultaneous demonstration of cellspecific epithelial markers. Human Pathology 25 42-46.

Bosland MC, Chung LWK, Greenberg NM, Ho S, Isaacs JT, Lane K, Peehl DM, Thompson TC, van Steenbrugge GJ \& van Weerden WM 1996 Recent advances in the development of animal and cell culture models for prostatic cancer research. Urologic Oncology 2 99-128.
Bostwick DG, Pacelli A \& Lopez-Beltran A 1996 Molecular biology of prostatic intraepithelial neoplasia. Prostate 29 117-134.

Brawer MK, Peehl DM, Stamey TA \& Bostwick DG 1985 Keratin immunoreactivity in the benign and neoplastic human prostate. Cancer Research 45 3663-3667.

Brawer MK, Bostwick DG, Peehl DM \& Stamey TA 1986 Keratin protein in human prostatic tissue and cell culture. Annals of the New York Academy of Sciences 455 729-731.

Bromfield GP, Meng A, Warde P \& Bristow RG 2003 Cell death in irradiated prostate epithelial cells: role of apoptotic and clonogenic cell kill. Prostate Cancer and Prostatic Disease 6 73-85.

Brothman AR, Maxwell TM, Cui J, Deubler DA \& Zhu XL 1999 Chromosomal clues to the development of prostate tumors. Prostate 38 303-312.

Bull JH, Ellison G, Patel A, Muir G, Walker M, Underwood M, Khan F \& Paskins L 2001 Identification of potential diagnostic markers of prostate cancer and prostatic intraepithelial neoplasia using cDNA microarray. British Journal of Cancer 84 1512-1519.

Burroughs KD, Oh J, Barrett JC \& DiAugustine RP 2003 Phosphatidylinositol 3-kinase and MEK1/2 are necessary for insulin-like growth factor-I-induced vascular endothelial growth factor synthesis in prostate epithelial cells: a role for hypoxia-inducible factor-1? Molecular Cancer Research $1312-322$.

Byrne RL, Leung H \& Neal DE 1996 Peptide growth factors in the prostate as mediators of stromal epithelial interaction. British Journal of Urology 77 627-633.

Campbell CL, Savarese DM, Quesenberry PJ \& Savarese TM 1999 Expression of multiple angiogenic cytokines in cultured normal human prostate epithelial cells: predominance of vascular endothelial growth factor. International Journal of Cancer 80 868-874.

Castro P, Giri D, Lamb D \& Ittmann M 2003 Cellular senescence in the pathogenesis of benign prostatic hyperplasia. Prostate 55 30-38.

Castro P, Xia C, Gomez L, Lamb DJ \& Ittmann M 2004 Interleukin- 8 expression is increased in senescent prostatic epithelial cells and promotes the development of benign prostatic hyperplasia. Prostate 60 153-159.

Chatterjee S, Brite KH \& Matsumura A 2001 Induction of apoptosis of integrin-expressing human prostate cancer cells by cyclic Arg-Gly-Asp peptides. Clinical Cancer Research 7 3006-3011.

Chen LM, Zhang X \& Chai KX 2004 Regulation of prostasin expression and function in the prostate. Prostate 59 1-12.

Chen Z, Fan Z, McNeal JE, Nolley R, Caldwell MC, Mahadevappa M, Zhang Z, Warrington JA \& Stamey TA 2003 Hepsin and maspin are inversely expressed in laser capture microdissectioned prostate cancer. Journal of Urology 169 1316-1319.

Chetcuti A, Margan SH, Russell P, Mann S, Millar DS, Clark SJ, Rogers J, Handelsman DJ \& Dong Q 2001 Loss of annexin II heavy and light chains in prostate cancer and its precursors. Cancer Research 61 6331-6334. 
Choi J, Shendrik I, Peacocke M, Peehl D, Buttyan R, Ikeguchi EF, Katz AE \& Benson MC 2000 Expression of senescence-associated beta-galactosidase in enlarged prostates from men with benign prostatic hyperplasia. Urology 56 160-166.

Chopra DP, Grignon DJ, Joiakim A, Mathieu PA, Mohamed A, Sakr WA, Powell IJ \& Sarkar FH 1996 Differential growth factor responses of epithelial cell cultures derived from normal human prostate, benign prostatic hyperplasia, and primary prostate carcinoma. Journal of Cellular Physiology 169 269-280.

Chopra DP, Menard RE, Januszewski J \& Mattingly RR 2004 TNF-alpha-mediated apoptosis in normal human prostate epithelial cells and tumor cell lines. Cancer Letters 203 145-154.

Coffey RN, Watson RW, Hegarty PK, Watson CL, Wolohan L, Brady HR, O'Keane C \& Fitzpatrick JM 2001 Priming prostate carcinoma cells for increased apoptosis is associated with up-regulation of the caspases. Cancer 92 2297-2308.

Cohen P, Peehl DM, Stamey TA, Wilson KF, Clemmons DR \& Rosenfeld RG 1993 Elevated levels of insulin-like growth factor-binding protein-2 in the serum of prostate cancer patients. Journal of Clinical Endocrinology and Metabolism 76 1031-1035.

Collins AT, Habib FK, Maitland NJ \& Neal DE 2001 Identification and isolation of human prostate epithelial stem cells based on alpha(2)beta(1)-integrin expression. Journal of Cell Science 114 3865-3872.

Culig Z, Hobisch A, Cronauer MV, Radmayr C, Hittmair A, Zhang J, Thurnher M, Bartsch G \& Klocker H 1996 Regulation of prostatic growth and function by peptide growth factors. Prostate 28 392-405.

Cussenot O, Berthon P, Cochand-Priollet B, Maitland NJ \& Le Duc A 1994 Immunocytochemical comparison of cultured normal epithelial prostatic cells with prostatic tissue sections. Experimental Cell Research 214 83-92.

Das R, Hammamieh R, Neill R, Melhem M \& Jett M 2001 Expression pattern of fatty acid-binding proteins in human normal and cancer prostate cells and tissues. Clinical Cancer Research 7 1706-1715.

Davila M, Frost AR, Grizzle WE \& Chakrabarti R 2003 LIM kinase 1 is essential for the invasive growth of prostate epithelial cells: implications in prostate cancer. Journal of Biological Chemistry 278 36868-36875.

Davis LD, Zhang W, Merseburger A, Young D, Xu L, Rhim JS, Moul JW, Srivastava S \& Sesterhenn IA 2002 p63 expression profile in normal and malignant prostate epithelial cells. Anticancer Research 22 3819-3825.

De Marzo AM, DeWeese TL, Platz EA, Meeker AK, Nakayama M, Epstein JI, Isaacs WB \& Nelson WG 2004 Pathological and molecular mechanisms of prostate carcinogenesis: implications for diagnosis, detection, prevention, and treatment. Journal of Cellular Biochemistry 91 459-477.

Delos S, Carsol JL, Fina F, Raynaud JP \& Martin PM 1998 5 alpha-reductase and 17 beta-hydroxysteroid dehydrogenase expression in epithelial cells from hyperplastic and malignant human prostate. International Journal of Cancer 75 840-846.

Dhanasekaran SM, Barrette TR, Ghosh D, Shah R, Varambally S, Kurachi K, Pienta KJ, Rubin MA \& Chinnaiyan AM 2001 Delineation of prognostic biomarkers in prostate cancer. Nature 412 822-826.

Djakiew D 2000 Dysregulated expression of growth factors and their receptors in the development of prostate cancer. Prostate 42 150-160.

Doll JA, Reiher FK, Crawford SE, Pins MR, Campbell SC \& Bouck NP 2001 Thrombospondin-1, vascular endothelial growth factor and fibroblast growth factor-2 are key functional regulators of angiogenesis in the prostate. Prostate 49 293-305.

Downing SR, Jackson P \& Russell PJ 2001 Mutations within the tumour suppressor gene p53 are not confined to a late event in prostate cancer progression. a review of the evidence. Urologic Oncology 6 103-110.

Dumble ML, Knight B, Quail EA \& Yeoh GC 2001 Hepatoblast-like cells populate the adult p53 knockout mouse liver: evidence for a hyperproliferative maturationarrested stem cell compartment. Cell Growth and Differentiation 12 223-231.

Dunlap N, Schwartz GG, Eads D, Cramer SD, Sherk AB, John V \& Koumenis C 2003 1alpha,25-dihydroxyvitamin $\mathrm{D}(3)$ (calcitriol) and its analogue, 19-nor-1alpha, $25(\mathrm{OH})(2) \mathrm{D}(2)$, potentiate the effects of ionising radiation on human prostate cancer cells. British Journal of Cancer 89 746-753.

El-Alfy M, Luu-The V, Huang XF, Berger L, Labrie F \& Pelletier G 1999 Localization of type 5 17beta-hydroxysteroid dehydrogenase, 3beta-hydroxysteroid dehydrogenase, and androgen receptor in the human prostate by in situ hybridization and immunocytochemistry. Endocrinology 140 1481-1491.

Etminan M, Takkouche B \& Caamano-Isorna F 2004 The role of tomato products and lycopene in the prevention of prostate cancer: a meta-analysis of observational studies. Cancer Epidemiology, Biomarkers and Prevention 13 340-345.

Ficazzola MA, Fraiman M, Gitlin J, Woo K, Melamed J, Rubin MA \& Walden PD 2001 Antiproliferative B cell translocation gene 2 protein is down-regulated posttranscriptionally as an early event in prostate carcinogenesis. Carcinogenesis 22 1271-1279.

Flatt PM, Price JO, Shaw A \& Pietenpol JA 1998 Differential cell cycle checkpoint response in normal human keratinocytes and fibroblasts. Cell Growth and Differentiation 9 535-543.

Fong CJ, Sherwood ER, Sutkowski DM, Abu-Jawdeh GM, Yokoo H, Bauer KD, Kozlowski JM \& Lee C 1991 Reconstituted basement membrane promotes morphological and functional differentiation of primary human prostatic epithelial cells. Prostate 19 221-235.

Gao J, Arnold JT \& Isaacs JT 2001 Conversion from a paracrine to an autocrine mechanism of 
androgen-stimulated growth during malignant transformation of prostatic epithelial cells. Cancer Research 61 5038-5044.

Garraway LA, Lin D, Signoretti S, Waltregny D, Dilks J, Bhattacharya N \& Loda M 2003 Intermediate basal cells of the prostate: in vitro and in vivo characterization. Prostate 55 206-218.

Ghosh J 2004 Rapid induction of apoptosis in prostate cancer cells by selenium: reversal by metabolites of arachidonate 5-lipoxygenase. Biochemical and Biophysical Research Communications 315 624-635.

Gingras S \& Simard J 1999 Induction of 3beta-hydroxysteroid dehydrogenase/isomerase type 1 expression by interleukin-4 in human normal prostate epithelial cells, immortalized keratinocytes, colon, and cervix cancer cell lines. Endocrinology $1404573-4584$.

Giri D, Ozen M \& Ittmann M 2001 Interleukin-6 is an autocrine growth factor in human prostate cancer. American Journal of Pathology 159 2159-2165.

Girinsky T, Koumenis C, Graeber TG, Peehl DM \& Giaccia AJ 1995 Attenuated response of p53 and p21 in primary cultures of human prostatic epithelial cells exposed to DNA-damaging agents. Cancer Research 55 3726-3731.

Glinsky GV, Krones-Herzig A, Glinskii AB \& Gebauer G 2003 Microarray analysis of xenograft-derived cancer cell lines representing multiple experimental models of human prostate cancer. Molecular Carcinogenesis 37 209-221.

Glinsky GV, Glinskii AB, Stephenson AJ, Hoffman RM \& Gerald WL 2004 Gene expression profiling predicts clinical outcome of prostate cancer. Journal of Clinical Investigation 113 913-923.

Gommersall LM, Khanim FL, Peehl DM, Doherty AH \& Campbell MJ 2004 Epigenetic repression of transcription by the vitamin $\mathrm{D}(3)$ receptor in prostate cancer cells. Journal of Steroid Biochemistry and Molecular Biology 89-90 251-256.

Goossens K, Deboel L, Swinnen JV, Roskams T, Manin M, Rombauts W \& Verhoeven G 2002 Both retinoids and androgens are required to maintain or promote functional differentiation in reaggregation cultures of human prostate epithelial cells. Prostate 53 34-49.

Grant ES, Batchelor KW \& Habib FK 1996 Androgen independence of primary epithelial cultures of the prostate is associated with a down-regulation of androgen receptor gene expression. Prostate 29 339-349.

Guo X, Knudsen BS, Peehl DM, Ruiz A, Bok D, Rando RR, Rhim JS, Nanus DM \& Gudas LJ 2002 Retinol metabolism and lecithin:retinol acyltransferase levels are reduced in cultured human prostate cancer cells and tissue specimens. Cancer Research 62 1654-1661.

Gupta S, Afaq F \& Mukhtar H 2001 Selective growthinhibitory, cell-cycle deregulatory and apoptotic response of apigenin in normal versus human prostate carcinoma cells. Biochemical and Biophysical Research Communications 287 914-920.

Hall JA, Maitland NJ, Stower M \& Lang SH 2002 Primary prostate stromal cells modulate the morphology and migration of primary prostate epithelial cells in type 1 collagen gels. Cancer Research 62 58-62.

Hammond LA, Van Krinks CH, Durham J, Tomkins SE, Burnett RD, Jones EL, Chandraratna RA \& Brown G 2001 Antagonists of retinoic acid receptors (RARs) are potent growth inhibitors of prostate carcinoma cells. British Journal of Cancer 85 453-462.

Han EK, Lim JT, Arber N, Rubin MA, Xing WQ \& Weinstein IB 1998 Cyclin D1 expression in human prostate carcinoma cell lines and primary tumors. Prostate 35 95-101.

Hart CA, Scott LJ, Bagley S, Bryden AA, Clarke NW \& Lang SH 2002 Role of proteolytic enzymes in human prostate bone metastasis formation: in vivo and in vitro studies. British Journal of Cancer 86 1136-1142.

Hayward SW, Wang Y, Cao M, Hom YK, Zhang B, Grossfeld GD, Sudilovsky D \& Cunha GR 2001 Malignant transformation in a nontumorigenic human prostatic epithelial cell line. Cancer Research $\mathbf{6 1}$ 8135-8142.

He XY, Yang YZ, Peehl DM, Lauderdale A, Schulz H \& Yang SY 2003 Oxidative 3alpha-hydroxysteroid dehydrogenase activity of human type 10 17betahydroxysteroid dehydrogenase. Journal of Steroid Biochemistry and Molecular Biology 87 191-198.

Hedlund TE, Johannes WU \& Miller GJ 2003 Soy isoflavonoid equol modulates the growth of benign and malignant prostatic epithelial cells in vitro. Prostate $\mathbf{5 4}$ 68-78.

Hobisch A, Rogatsch H, Hittmair A, Fuchs D, Bartsch G Jr, Klocker H, Bartsch G \& Culig Z 2000

Immunohistochemical localization of interleukin-6 and its receptor in benign, premalignant and malignant prostate tissue. Journal of Pathology 191 239-244.

Hsu AL, Ching TT, Wang DS, Song X, Rangnekar VM \& Chen CS 2000 The cyclooxygenase-2 inhibitor celecoxib induces apoptosis by blocking Akt activation in human prostate cancer cells independently of Bcl-2. Journal of Biological Chemistry 275 11397-11403.

Hudson DL, O'Hare M, Watt FM \& Masters JR 2000 Proliferative heterogeneity in the human prostate: evidence for epithelial stem cells. Laboratory Investigation 80 1243-1250.

Humphrey PA, Zhu X, Zarnegar R, Swanson PE, Ratliff TL, Vollmer RT \& Day ML 1995 Hepatocyte growth factor and its receptor (c-MET) in prostatic carcinoma. American Journal of Pathology 147 386-396.

Husain SR, Kawakami K, Kawakami M \& Puri RK 2003 Interleukin-4 receptor-targeted cytotoxin therapy of androgen-dependent and -independent prostate carcinoma in xenograft models. Molecular Cancer Therapeutics 2 245-254.

Ide H, Seligson DB, Memarzadeh S, Xin L, Horvath S, Dubey P, Flick MB, Kacinski BM, Palotie A \& Witte ON 2002 Expression of colony-stimulating factor 1 receptor during prostate development and prostate cancer progression. PNAS 99 14404-14409. 
Isaacs JT 2000 Apoptosis: translating theory to therapy for prostate cancer. Journal of the National Cancer Institute 92 1367-1369.

Ittman M \& Mansukhani A 1997 Expression of fibroblast growth factors (FGFs) and FGF receptors in human prostate. Journal of Urology 157 351-356.

Iype PT, Iype LE, Verma M \& Kaighn ME 1998

Establishment and characterization of immortalized human cell lines from prostatic carcinoma and benign prostatic hyperplasia. International Journal of Oncology 12 257-263.

Jack GS, Brash AR, Olson SJ, Manning S, Coffey CS, Smith JA Jr \& Shappell SB 2000 Reduced 15-lipoxygenase-2 immunostaining in prostate adenocarcinoma: correlation with grade and expression in high-grade prostatic intraepithelial neoplasia. Human Pathology 31 1146-1154.

Jarrard DF, Kinoshita H, Shi Y, Sandefur C, Hoff D, Meisner LF, Chang C, Herman JG, Isaacs WB \& Nassif N 1998 Methylation of the androgen receptor promoter $\mathrm{CpG}$ island is associated with loss of androgen receptor expression in prostate cancer cells. Cancer Research $\mathbf{5 8}$ 5310-5314.

Kanagawa K, Sugimura K, Kuratsukuri K, Ikemoto S, Kishimoto T \& Nakatani T 2003 Norepinephrine activates P44 and P42 MAPK in human prostate stromal and smooth muscle cells but not in epithelial cells. Prostate 56 313-318.

Kennedy AR \& Wan XS 2002 Effects of the Bowman-Birk inhibitor on growth, invasion, and clonogenic survival of human prostate epithelial cells and prostate cancer cells. Prostate 50 125-133.

Kim SJ, Johnson M, Koterba K, Herynk MH, Uehara H \& Gallick GE 2003 Reduced c-Met expression by an adenovirus expressing a c-Met ribozyme inhibits tumorigenic growth and lymph node metastases of PC3LN4 prostate tumor cells in an orthotopic nude mouse model. Clinical Cancer Research 9 5161-5170.

Kiviharju TM, Lecane PS, Sellers RG \& Peehl DM 2002 Antiproliferative and proapoptotic activities of triptolide (PG490), a natural product entering clinical trials, on primary cultures of human prostatic epithelial cells. Clinical Cancer Research 8 2666-2674.

Klein RD \& Fischer SM 2002 Black tea polyphenols inhibit IGF-I-induced signaling through Akt in normal prostate epithelial cells and Du145 prostate carcinoma cells. Carcinogenesis 23 217-221.

Klein RD, Maliner-Jongewaard MS, Udayakumar TS, Boyd JL, Nagle RB \& Bowden GT 1999 Promatrilysin expression is induced by fibroblast growth factors in the prostatic carcinoma cell line LNCaP but not in normal primary prostate epithelial cells. Prostate 41 215-223.

Koeffler HP 2003 Peroxisome proliferator-activated receptor gamma and cancers. Clinical Cancer Research 9 1-9.

Kooistra A, Elissen NM, Konig JJ, Vermey M, van der Kwast TH, Romijn JC \& Schroder FH 1995 Immunocytochemical characterization of explant cultures of human prostatic stromal cells. Prostate 27 42-49.
Krege JH, Hodgin JB, Couse JF, Enmark E, Warner M, Mahler JF, Sar M, Korach KS, Gustafsson JA \& Smithies O 1998 Generation and reproductive phenotypes of mice lacking estrogen receptor beta. PNAS 95 15677-15682.

Krishnan AV, Peehl DM \& Feldman D 2003 Inhibition of prostate cancer growth by vitamin D: regulation of target gene expression. Journal of Cellular Biochemistry $\mathbf{8 8}$ 363-371.

Kyprianou N, Tu H \& Jacobs SC 1996 Apoptotic versus proliferative activities in human benign prostatic hyperplasia. Human Pathology 27 668-675.

Lang SH, Clarke NW, George NJ, Allen TD \& Testa NG 1998 Interaction of prostate epithelial cells from benign and malignant tumor tissue with bone-marrow stroma. Prostate 34 203-213.

Lang SH, Stark M, Collins A, Paul AB, Stower MJ \& Maitland NJ 2001 Experimental prostate epithelial morphogenesis in response to stroma and threedimensional matrigel culture. Cell Growth and Differentiation 12 631-640.

Lau KM, LaSpina M, Long J \& Ho SM 2000 Expression of estrogen receptor (ER)-alpha and ER-beta in normal and malignant prostatic epithelial cells: regulation by methylation and involvement in growth regulation. Cancer Research 60 3175-3182.

Leav I, McNeal JE, Kwan PW, Komminoth P \& Merk FB 1996 Androgen receptor expression in prostatic dysplasia (prostatic intraepithelial neoplasia) in the human prostate: an immunohistochemical and in situ hybridization study. Prostate 29 137-145.

Leav I, Lau KM, Adams JY, McNeal JE, Taplin ME, Wang J, Singh H \& Ho SM 2001 Comparative studies of the estrogen receptors beta and alpha and the androgen receptor in normal human prostate glands, dysplasia, and in primary and metastatic carcinoma. American Journal of Pathology 159 79-92.

Lebedeva IV, Sarkar D, Su ZZ, Kitada S, Dent P, Stein CA, Reed JC \& Fisher PB 2003 Bcl-2 and Bcl-x(L) differentially protect human prostate cancer cells from induction of apoptosis by melanoma differentiation associated gene-7, mda-7/IL-24. Oncogene 22 8758-8773.

Lecane PS, Kiviharju TM, Sellers RG \& Peehl DM 2003 Leptomycin B stabilizes and activates p53 in primary prostatic epithelial cells and induces apoptosis in the LNCaP cell line. Prostate 54 258-267.

Lee KL \& Peehl DM 2004 Molecular and cellular pathogenesis of benign prostatic hyperplasia. Journal of Urology 172 1784-1791.

Lee SW, Reimer CL, Fang L, Iruela-Arispe ML \& Aaronson SA 2000 Overexpression of kinase-associated phosphatase (KAP) in breast and prostate cancer and inhibition of the transformed phenotype by antisense KAP expression. Molecular and Cellular Biology 20 1723-1732.

Lewis KC \& Hochadel JF 1999 Retinoid metabolism in the prostate: effects of administration of the synthetic retinoid N-(4-hydroxyphenyl)retinamide. Cancer Research 59 5947-5955. 
Lim JT, Piazza GA, Han EK, Delohery TM, Li H, Finn TS, Buttyan R, Yamamoto H, Sperl GJ, Brendel K et al. 1999 Sulindac derivatives inhibit growth and induce apoptosis in human prostate cancer cell lines. Biochemical Pharmacology 58 1097-1107.

Lin XS, Denmeade SR, Cisek L \& Isaacs JT 1997 Mechanism and role of growth arrest in programmed (apoptotic) death of prostatic cancer cells induced by thapsigargin. Prostate 33 201-207.

Liu AY 2000 Differential expression of cell surface molecules in prostate cancer cells. Cancer Research 60 3429-3434.

Liu AY \& Peehl DM 2001 Characterization of cultured human prostatic epithelial cells by cluster designation antigen expression. Cell and Tissue Research 305 389-397.

Liu AY \& True LD 2002 Characterization of prostate cell types by CD cell surface molecules. American Journal of Pathology 160 37-43.

Liu AY, Corey E, Vessella RL, Lange PH, True LD, Huang GM, Nelson PS \& Hood L $1997 a$ Identification of differentially expressed prostate genes: increased expression of transcription factor ETS-2 in prostate cancer. Prostate 30 145-153.

Liu AY, True LD, LaTray L, Nelson PS, Ellis WJ, Vessella RL, Lange PH, Hood L \& van den Engh G $1997 b$ Cell-cell interaction in prostate gene regulation and cytodifferentiation. PNAS 94 10705-10710.

Liu AY, Nelson PS, van den Engh G \& Hood L 2002 Human prostate epithelial cell-type cDNA libraries and prostate expression patterns. Prostate 50 92-103.

Liu JW, Shen JJ, Tanzillo-Swarts A, Bhatia B, Maldonado CM, Person MD, Lau SS \& Tang DG 2003 Annexin II expression is reduced or lost in prostate cancer cells and its re-expression inhibits prostate cancer cell migration. Oncogene 22 1475-1485.

Lokeshwar VB, Rubinowicz D, Schroeder GL, Forgacs E, Minna JD, Block NL, Nadji M \& Lokeshwar BL 2001 Stromal and epithelial expression of tumor markers hyaluronic acid and HYAL1 hyaluronidase in prostate cancer. Journal of Biological Chemistry 276 11922-11932.

Mahmud S, Franco E \& Aprikian A 2004 Prostate cancer and use of nonsteroidal anti-inflammatory drugs: systematic review and meta-analysis. British Journal of Cancer 90 93-99.

Marinese D, Patel R \& Walden PD 2003 Mechanistic investigation of the adrenergic induction of ventral prostate hyperplasia in mice. Prostate 54 230-237.

Maroni PD, Koul S, Meacham RB \& Koul HK 2004 Mitogen activated protein kinase signal transduction pathways in the prostate. Cell Communication and Signaling 25.

Martikainen P, Kyprianou N \& Isaacs JT 1990 Effect of transforming growth factor-beta 1 on proliferation and death of rat prostatic cells. Endocrinology 127 2963-2968.

McKeon F 2004 p63 and the epithelial stem cell: more than status quo? Genes and Development 18 465-469.

McNeal JE 1988 Significance of duct-acinar dysplasia in prostatic carcinogenesis. Prostate 13 91-102.
McNeal JE, Villers A, Redwine EA, Freiha FS \& Stamey TA 1991 Microcarcinoma in the prostate: its association with duct-acinar dysplasia. Human Pathology 22 644-652.

McNeal JE, Haillot O \& Yemoto C 1995 Cell proliferation in dysplasia of the prostate: analysis by PCNA immunostaining. Prostate 27 258-268.

Merchant DJ 1990 Primary explant culture of human prostate tissue: a model for the study of prostate physiology and pathology. Prostate 16 103-126.

Meyer KM, Hess SM, Tlsty TD \& Leadon SA 1999 Human mammary epithelial cells exhibit a differential p53mediated response following exposure to ionizing radiation or UV light. Oncogene 18 5795-5805.

Michalaki V, Syrigos K, Charles P \& Waxman J 2004 Serum levels of IL-6 and TNF-alpha correlate with clinicopathological features and patient survival in patients with prostate cancer. British Journal of Cancer 90 2312-2316.

Miniati DN, Chang Y, Shu WP, Peehl DM \& Liu BC 1996 Role of prostatic basal cells in the regulation and suppression of human prostate cancer cells. Cancer Letters 104 137-144.

Mitchen J, Oberley T \& Wilding G 1997 Extended culturing of androgen-responsive human primary epithelial prostate cell isolates by continuous treatment with interstitial collagenase. Prostate 30 7-19.

Moore MG, Wetterau LA, Francis MJ, Peehl DM \& Cohen P 2003 Novel stimulatory role for insulin-like growth factor binding protein-2 in prostate cancer cells. International Journal of Cancer 105 14-19.

Nelson PS, Plymate SR, Wang K, True LD, Ware JL, Gan L, Liu AY \& Hood L 1998 Hevin, an antiadhesive extracellular matrix protein, is down-regulated in metastatic prostate adenocarcinoma. Cancer Research 58 232-236.

Nesterov A, Ivashchenko Y \& Kraft AS 2002 Tumor necrosis factor-related apoptosis-inducing ligand (TRAIL) triggers apoptosis in normal prostate epithelial cells. Oncogene 21 1135-1140.

Nie D, Che M, Zacharek A, Qiao Y, Li L, Li X, Lamberti M, Tang K, Cai Y, Guo Y et al. 2004 Differential expression of thromboxane synthase in prostate carcinoma: role in tumor cell motility. American Journal of Pathology 164 429-439.

Nojima D, Li LC, Dharia A, Perinchery G, Ribeiro-Filho L, Yen TS \& Dahiya R 2001 CpG hypermethylation of the promoter region inactivates the estrogen receptor-beta gene in patients with prostate carcinoma. Cancer 92 2076-2083.

Obermuller-Jevic UC, Olano-Martin E, Corbacho AM, Eiserich JP, van der Vliet A, Valacchi G, Cross CE \& Packer L 2003 Lycopene inhibits the growth of normal human prostate epithelial cells in vitro. Journal of Nutrition 133 3356-3360.

Pakneshan P, Xing RH \& Rabbani SA 2003 Methylation status of uPA promoter as a molecular mechanism 
regulating prostate cancer invasion and growth in vitro and in vivo. FASEB Journal 17 1081-1088.

Pantel K, Dickmanns A, Zippelius A, Klein C, Shi J, Hoechtlen-Vollmar W, Schlimok G, Weckermann D, Oberneder R, Fanning E et al. 1995 Establishment of micrometastatic carcinoma cell lines: a novel source of tumor cell vaccines. Journal of the National Cancer Institute 87 1162-1168.

Paris PL, Albertson DG, Alers JC, Andaya A, Carroll P, Fridlyand J, Jain AN, Kamkar S, Kowbel D, Krijtenburg PJ et al. 2003 High-resolution analysis of paraffin-embedded and formalin-fixed prostate tumors using comparative genomic hybridization to genomic microarrays. American Journal of Pathology $162763-770$.

Pasquali D, Rossi V, Esposito D, Abbondanza C, Puca GA, Bellastella A \& Sinisi AA 2001 Loss of estrogen receptor beta expression in malignant human prostate cells in primary cultures and in prostate cancer tissues. Journal of Clinical Endocrinology and Metabolism 86 2051-2055.

Patel S, Turner PR, Stubberfield C, Barry E, Rohlff CR, Stamps A, McKenzie E, Young K, Tyson K, Terrett J et al. 2002 Hyaluronidase gene profiling and role of hyal-1 overexpression in an orthotopic model of prostate cancer. International Journal of Cancer 97 416-424.

Peehl DM 1996 Cellular biology of prostatic growth factors. Prostate. Supplement 6 74-78.

Peehl DM 2004 Are primary cultures realistic models of prostate cancer? Journal of Cellular Biochemistry 91 185-195.

Peehl DM \& Feldman D 2003 The role of vitamin D and retinoids in controlling prostate cancer progression. Endocrine-Related Cancer 10 131-140.

Peehl DM \& Rubin JS 1995 Keratinocyte growth factor: an androgen-regulated mediator of stromal-epithelial interactions in the prostate. World Journal of Urology 13 312-317.

Peehl DM \& Sellers RG 2002 Epithelial cell culture: prostate. In Methods of Tissue Engineering, pp 247-261. Eds A Atala \& R Lanza. San Diego, CA: Academic Press.

Peehl DM, Wong ST, Bazinet M \& Stamey TA 1989 In vitro studies of human prostatic epithelial cells: attempts to identify distinguishing features of malignant cells. Growth Factors 1 237-250.

Peehl DM, Wong ST \& Stamey TA 1993 Vitamin A regulates proliferation and differentiation of human prostatic epithelial cells. Prostate 23 69-78.

Peehl DM, Erickson E, Malspeis L, Mayo J, Camalier RF, Monks A, Cronise P, Paull K \& Grever MR 1994a In vitro prostate cancer drug screen. In Fundamental Approaches to the Diagnosis and Treatment of Prostate Cancer and $B P H$, pp 57-71. Eds K Imai, J Shimazaki \& JP Karr. New York: Academic Press.

Peehl DM, Leung GK \& Wong ST $1994 b$ Keratin expression: a measure of phenotypic modulation of human prostatic epithelial cells by growth inhibitory factors. Cell and Tissue Research 277 11-18.
Peehl DM, Wong ST, Cramer SD, Gross C \& Feldman D 1995 Suramin, hydrocortisone and retinoic acid modify inhibitory effects of 1,25-dihydroxyvitamin $\mathrm{D}_{3}$ on prostatic epithelial cells. Urologic Oncology 1 188-294.

Peehl DM, Sellers RG \& McNeal JE 1996 Keratin 19 in the adult human prostate: tissue and cell culture studies. Cell and Tissue Research 285 171-176.

Peehl DM, Seto E, Hsu JY \& Feldman D 2002 Preclinical activity of ketoconazole in combination with calcitriol or the vitamin D analogue EB 1089 in prostate cancer cells. Journal of Urology 168 1583-1588.

Pisters LL, Troncoso P, Zhau HE, Li W, von Eschenbach AC \& Chung LW 1995 c-Met proto-oncogene expression in benign and malignant human prostate tissues. Journal of Urology 154 293-298.

Pizer ES, Pflug BR, Bova GS, Han WF, Udan MS \& Nelson JB 2001 Increased fatty acid synthase as a therapeutic target in androgen-independent prostate cancer progression. Prostate 47 102-110.

Planz B, Wang Q, Kirley SD, Marberger M \& McDougal WS 2001 Regulation of keratinocyte growth factor receptor and androgen receptor in epithelial cells of the human prostate. Journal of Urology 166 678-683.

Pollak MN, Schernhammer ES \& Hankinson SE 2004 Insulin-like growth factors and neoplasia. Nature Reviews. Cancer 4 505-518.

Posey JT, Soloway MS, Ekici S, Sofer M, Civantos F, Duncan RC \& Lokeshwar VB 2003 Evaluation of the prognostic potential of hyaluronic acid and hyaluronidase (HYAL1) for prostate cancer. Cancer Research $\mathbf{6 3}$ 2638-2644.

Putz E, Witter K, Offner S, Stosiek P, Zippelius A, Johnson J, Zahn R, Riethmuller G \& Pantel K 1999

Phenotypic characteristics of cell lines derived from disseminated cancer cells in bone marrow of patients with solid epithelial tumors: establishment of working models for human micrometastases. Cancer Research 59 241-248.

Rao A, Woodruff RD, Wade WN, Kute TE \& Cramer SD 2002 Genistein and vitamin D synergistically inhibit human prostatic epithelial cell growth. Journal of Nutrition 132 3191-3194.

Rayford W, Noble MJ, Austenfeld MA, Weigel J, Mebust WK \& Shah GV 1997 Muscarinic cholinergic receptors promote growth of human prostate cancer cells. Prostate 30 160-166.

Rizner TL, Lin HK, Peehl DM, Steckelbroeck S, Bauman DR \& Penning TM 2003 Human type 3 3alphahydroxysteroid dehydrogenase (aldo-keto reductase 1C2) and androgen metabolism in prostate cells. Endocrinology 144 2922-2932.

Robinson EJ, Neal DE \& Collins AT 1998 Basal cells are progenitors of luminal cells in primary cultures of differentiating human prostatic epithelium. Prostate 37 149-160.

Ropiquet F, Giri D, Kwabi-Addo B, Mansukhani A \& Ittmann M 2000 Increased expression of fibroblast growth 
factor 6 in human prostatic intraepithelial neoplasia and prostate cancer. Cancer Research 60 4245-4250.

Rumpold H, Heinrich E, Untergasser G, Hermann M, Pfister G, Plas E \& Berger P 2002 Neuroendocrine differentiation of human prostatic primary epithelial cells in vitro. Prostate 53 101-108.

Salnikow K, Costa M, Figg WD \& Blagosklonny MV 2000 Hyperinducibility of hypoxia-responsive genes without p53/p21-dependent checkpoint in aggressive prostate cancer. Cancer Research 60 5630-5634.

Sandhu C, Peehl DM \& Slingerland J 2000 p16INK4A mediates cyclin dependent kinase 4 and 6 inhibition in senescent prostatic epithelial cells. Cancer Research 60 2616-2622.

Schalken JA \& van Leenders G 2003 Cellular and molecular biology of the prostate: stem cell biology. Urology $\mathbf{6 2}$ $11-20$.

Schwarze SR, Shi Y, Fu VX, Watson PA \& Jarrard DF 2001 Role of cyclin-dependent kinase inhibitors in the growth arrest at senescence in human prostate epithelial and uroepithelial cells. Oncogene 20 8184-8192.

Schwarze SR, DePrimo SE, Grabert LM, Fu VX, Brooks JD \& Jarrard DF 2002 Novel pathways associated with bypassing cellular senescence in human prostate epithelial cells. Journal of Biological Chemistry 277 14877-14883.

Schwarze SR, Fu VX \& Jarrard DF 2003 Cdc37 enhances proliferation and is necessary for normal human prostate epithelial cell survival. Cancer Research 63 4614-4619.

Shappell SB, Boeglin WE, Olson SJ, Kasper S \& Brash AR 1999 15-lipoxygenase-2 (15-LOX-2) is expressed in benign prostatic epithelium and reduced in prostate adenocarcinoma. American Journal of Pathology 155 235-245.

Sheng S, Carey J, Seftor EA, Dias L, Hendrix MJ \& Sager R 1996 Maspin acts at the cell membrane to inhibit invasion and motility of mammary and prostatic cancer cells. PNAS 93 11669-11674.

Sherwood ER, Berg LA, McEwan RN, Pasciak RM, Kozlowski JM \& Lee C 1989 Two-dimensional protein profiles of cultured stromal and epithelial cells from hyperplastic human prostate. Journal of Cellular Biochemistry 40 201-214.

Shou J, Soriano R, Hayward SW, Cunha GR, Williams PM \& Gao WQ 2002 Expression profiling of a human cell line model of prostatic cancer reveals a direct involvement of interferon signaling in prostate tumor progression. PNAS 99 2830-2835.

Signoretti S \& Loda M 2001 Estrogen receptor beta in prostate cancer: brake pedal or accelerator? American Journal of Pathology 159 13-16.

Signoretti S, Waltregny D, Dilks J, Isaac B, Lin D, Garraway L, Yang A, Montironi R, McKeon F \& Loda M 2000 p63 is a prostate basal cell marker and is required for prostate development. American Journal of Pathology 157 1769-1775.

Simpson MA, Wilson CM \& McCarthy JB 2002 Inhibition of prostate tumor cell hyaluronan synthesis impairs subcutaneous growth and vascularization in immunocompromised mice. American Journal of Pathology 161 849-857.

Sinisi AA, Bellastella A, Prezioso D, Nicchio MR, Lotti T, Salvatore M \& Pasquali D 1997 Different expression patterns of somatostatin receptor subtypes in cultured epithelial cells from human normal prostate and prostate cancer. Journal of Clinical Endocrinology and Metabolism 82 2566-2569.

Sinisi AA, Chieffi P, Pasquali D, Kisslinger A, Staibano S, Bellastella A \& Tramontano D 2002 EPN: a novel epithelial cell line derived from human prostate tissue. In Vitro Cellular and Developmental Biology. Animal $\mathbf{3 8}$ 165-172.

Smitherman AB, Mohler JL, Maygarden SJ \& Ornstein DK 2004 Expression of annexin I, II and VII proteins in androgen stimulated and recurrent prostate cancer. Journal of Urology 171 916-920.

Soda H, Raymond E, Sharma S, Lawrence R, Davidson K, Oka M, Kohno S, Izbicka E \& Von Hoff DD 2000 Effects of androgens on telomerase activity in normal and malignant prostate cells in vitro. Prostate 43 161-168.

Solakoglu O, Maierhofer C, Lahr G, Breit E, Scheunemann P, Heumos I, Pichlmeier U, Schlimok G, Oberneder R, Kollermann MW et al. 2002 Heterogeneous proliferative potential of occult metastatic cells in bone marrow of patients with solid epithelial tumors. PNAS 99 2246-2251.

Stamey TA, Caldwell MC, McNeal JE, Nolley R, Hemenez M \& Downs J 2004 The PSA era in the United States is over for prostate cancer: what happened in the past 20 years? Journal of Urology 172 1297-1301.

Stearns ME, Hu Y \& Wang M 2003a IL-10 signaling via IL$10 \mathrm{E} 1$ is dependent on tyrosine phosphorylation in the IL$10 \mathrm{R}$ alpha chain in human primary prostate cancer cell lines. Oncogene 22 3781-3791.

Stearns ME, Wang M, Hu Y \& Garcia FU 2003b Interleukin10 activation of the interleukin-10E1 pathway and tissue inhibitor of metalloproteinase-1 expression is enhanced by proteasome inhibitors in primary prostate tumor lines. Molecular Cancer Research 1 631-642.

Stearns ME, Wang M, Hu Y, Garcia FU \& Rhim J $2003 c$ Interleukin 10 blocks matrix metalloproteinase- 2 and membrane type 1-matrix metalloproteinase synthesis in primary human prostate tumor lines. Clinical Cancer Research 9 1191-1199.

Stepanova L, Yang G, DeMayo F, Wheeler TM, Finegold M, Thompson TC \& Harper JW 2000 Induction of human $\mathrm{Cdc} 37$ in prostate cancer correlates with the ability of targeted $\mathrm{Cdc} 37$ expression to promote prostatic hyperplasia. Oncogene 19 2186-2193.

Sterling, KM Jr \& Cutroneo KR 2004 Constitutive and inducible expression of cytochromes P4501A (CYP1A and CYP1A2) in normal prostate and prostate cancer cells. Journal of Cellular Biochemistry 91 423-429.

Subbarayan V, Sabichi AL, Llansa N, Lippman SM \& Menter DG 2001 Differential expression of cyclooxygenase- 2 and its regulation by tumor necrosis 
factor-alpha in normal and malignant prostate cells. Cancer Research 61 2720-2726.

Sumitomo M, Asano T, Asakuma J, Nanus DM \& Hayakawa M 2004 Chemosensitization of androgenindependent prostate cancer with neutral endopeptidase. Clinical Cancer Research 10 260-266.

Sutkowski DM, Fong CJ, Sensibar JA, Rademaker AW, Sherwood ER, Kozlowski JM \& Lee C 1992 Interaction of epidermal growth factor and transforming growth factor beta in human prostatic epithelial cells in culture. Prostate 21 133-143.

Takahashi S, Urano T, Tsuchiya F, Fujimura T, Kitamura T, Ouchi Y, Muramatsu M \& Inoue S 2003 EBAG9/RCAS1 expression and its prognostic significance in prostatic cancer. International Journal of Cancer 106 310-315.

Tang DG, Li L, Chopra DP \& Porter AT 1998 Extended survivability of prostate cancer cells in the absence of trophic factors: increased proliferation, evasion of apoptosis, and the role of apoptosis proteins. Cancer Research 58 3466-3479.

Tang S, Bhatia B, Maldonado CJ, Yang P, Newman RA, Liu J, Chandra D, Traag J, Klein RD, Fischer SM et al. 2002 Evidence that arachidonate 15-lipoxygenase 2 is a negative cell cycle regulator in normal prostate epithelial cells. Journal of Biological Chemistry 277 16189-16201.

Tekur S, Lau KM, Long J, Burnstein K \& Ho SM 2001 Expression of RFG/ELE1alpha/ARA70 in normal and malignant prostatic epithelial cell cultures and lines: regulation by methylation and sex steroids. Molecular Carcinogenesis 30 1-13.

Thebault S, Roudbaraki M, Sydorenko V, Shuba Y, Lemonnier L, Slomianny C, Dewailly E, Bonnal JL, Mauroy B, Skryma R et al. 2003 Alpha1-adrenergic receptors activate $\mathrm{Ca}(2+)$-permeable cationic channels in prostate cancer epithelial cells. Journal of Clinical Investigation 111 1691-1701.

Tran CP, Lin C, Yamashiro J \& Reiter RE 2002 Prostate stem cell antigen is a marker of late intermediate prostate epithelial cells. Molecular Cancer Research 1 113-121.

Tsujimura A, Koikawa Y, Salm S, Takao T, Coetzee S, Moscatelli D, Shapiro E, Lepor H, Sun TT \& Wilson EL 2002 Proximal location of mouse prostate epithelial stem cells: a model of prostatic homeostasis. Journal of Cell Biology 157 1257-1265.

Udayakumar TS, Klein RD, Maliner MS, Nagle RB \& Bowden GT 2001 Aberrant expression of fibroblast growth factor receptor-1 in prostate epithelial cells allows induction of promatrilysin expression by fibroblast growth factors. International Journal of Cancer 91 187-192.

Untergasser G, Koch HB, Menssen A \& Hermeking H 2002 Characterization of epithelial senescence by serial analysis of gene expression: identification of genes potentially involved in prostate cancer. Cancer Research 62 6255-6262.

Uzgare AR, Xu Y \& Isaacs JT 2004 In vitro culturing and characteristics of transit amplifying epithelial cells from human prostate tissue. Journal of Cellular Biochemistry 91 196-205.

van Bokhoven A, Varella-Garcia M, Korch C, Johannes WU, Smith EE, Miller HL, Nordeen SK, Miller GJ \& Lucia MS 2003 Molecular characterization of human prostate carcinoma cell lines. Prostate 57 205-225.

van Leenders G, Dijkman H, Hulsbergen-van de Kaa C, Ruiter D \& Schalken J 2000 Demonstration of intermediate cells during human prostate epithelial differentiation in situ and in vitro using triple-staining confocal scanning microscopy. Laboratory Investigation 80 1251-1258.

van Leenders G, van Balken B, Aalders T, Hulsbergen-van de Kaa C, Ruiter D \& Schalken J 2002 Intermediate cells in normal and malignant prostate epithelium express cMET: implications for prostate cancer invasion. Prostate 51 98-107.

Varani J, Hattori Y, Dame MK, Schmidt T, Murphy HS, Johnson KJ \& Wojno KJ 2001 Matrix metalloproteinases (MMPs) in fresh human prostate tumour tissue and organ-cultured prostate tissue: levels of collagenolytic and gelatinolytic MMPs are low, variable and different in fresh tissue versus organ-cultured tissue. British Journal of Cancer 84 1076-1083.

Vicentini C, Festuccia C, Angelucci A, Gravina GL, Muzi P, Eleuterio E, Miano R, Marronaro A, Tubaro A \& Bologna M 2002 Bicalutamide dose-dependently inhibits proliferation in human prostatic carcinoma cell lines and primary cultures. Anticancer Research 22 2917-2922.

Vicentini C, Festuccia C, Gravina GL, Angelucci A, Marronaro A \& Bologna M 2003 Prostate cancer cell proliferation is strongly reduced by the epidermal growth factor receptor tyrosine kinase inhibitor ZD1839 in vitro on human cell lines and primary cultures. Journal of Cancer Research and Clinical Oncology 129 165-174.

Vieweg J, Boczkowski D, Roberson KM, Edwards DW, Philip M, Philip R, Rudoll T, Smith C, Robertson C \& Gilboa E 1995 Efficient gene transfer with adenoassociated virus-based plasmids complexed to cationic liposomes for gene therapy of human prostate cancer. Cancer Research 55 2366-2372.

Wallen E, Sellers RG \& Peehl DM 2000 Brefeldin A induces p53-independent apoptosis in primary cultures of human prostatic cancer cells. Journal of Urology 164 836-841.

Wang J, Torbenson M, Wang Q, Ro JY \& Becich M 2003 Expression of inducible nitric oxide synthase in paired neoplastic and non-neoplastic primary prostate cell cultures and prostatectomy specimen. Urologic Oncology 21 117-122.

Wang S, DeGroff VL \& Clinton SK 2003 Tomato and soy polyphenols reduce insulin-like growth factor-Istimulated rat prostate cancer cell proliferation and apoptotic resistance in vitro via inhibition of intracellular signaling pathways involving tyrosine kinase. Journal of Nutrition 133 2367-2376. 
Ware JL 1994 Prostate cancer progression. Implications of histopathology. American Journal of Pathology 145 983-993.

Webber MM, Bello D \& Quader S 1996 Immortalized and tumorigenic adult human prostatic epithelial cell lines: characteristics and applications. Part 1. Cell markers and immortalized nontumorigenic cell lines. Prostate 29 386-394.

Webber MM, Bello D \& Quader S 1997 Immortalized and tumorigenic adult human prostatic epithelial cell lines: characteristics and applications Part 2. Tumorigenic cell lines. Prostate 30 58-64.

Welsh JB, Sapinoso LM, Su AI, Kern SG, Wang-Rodriguez J, Moskaluk CA, Frierson HF Jr \& Hampton GM 2001 Analysis of gene expression identifies candidate markers and pharmacological targets in prostate cancer. Cancer Research 61 5974-5978.

Wilson MJ, Sellers RG, Wiehr C, Melamud O, Pei D \& Peehl DM 2002 Expression of matrix metalloproteinase-2 and -9 and their inhibitors, tissue inhibitor of metalloproteinase1 and -2 , in primary cultures of human prostatic stromal and epithelial cells. Journal of Cellular Physiology 191 208-216.

Wu GJ, Varma VA, Wu MW, Wang SW, Qu P, Yang H, Petros JA, Lim SD \& Amin MB 2001 Expression of a human cell adhesion molecule, MUC18, in prostate cancer cell lines and tissues. Prostate 48 305-315.

Xiao D, Srivastava SK, Lew KL, Zeng Y, Hershberger P, Johnson CS, Trump DL \& Singh SV 2003 Allyl isothiocyanate, a constituent of cruciferous vegetables, inhibits proliferation of human prostate cancer cells by causing G2/M arrest and inducing apoptosis.

Carcinogenesis 24 891-897.

Xin H, Curry J, Johnstone RW, Nickoloff BJ \& Choubey D 2003 Role of IFI 16, a member of the interferon-inducible p200-protein family, in prostate epithelial cellular senescence. Oncogene 22 4831-4840.

Xu Y, Iyengar S, Roberts RL, Shappell SB \& Peehl DM 2003 Primary culture model of peroxisome proliferator-activated receptor gamma activity in prostate cancer cells. Journal of Cellular Physiology 196 131-143.

Yacoe ME, Sommer G \& Peehl D 1991 In vitro proton spectroscopy of normal and abnormal prostate. Magnetic Resonance in Medicine 19 429-438.

Yegnasubramanian S, Kowalski J, Gonzalgo ML, Zahurak M, Piantadosi S, Walsh PC, Bova GS, De Marzo AM, Isaacs WB \& Nelson WG 2004 Hypermethylation of CpG islands in primary and metastatic human prostate cancer. Cancer Research 64 1975-1986.

You X, Yu HM, Cohen-Gould L, Cao B, Symons M, Vande Woude GF \& Knudsen BS 2003 Regulation of migration of primary prostate epithelial cells by secreted factors from prostate stromal cells. Experimental Cell Research 288 246-256.

Zhang J, Jung K, Lein M, Kristiansen G, Rudolph B, Hauptmann S, Schnorr D, Loening SA \& Lichtinghagen R 2002 Differential expression of matrix metalloproteinases and their tissue inhibitors in human primary cultured prostatic cells and malignant prostate cell lines. Prostate 50 38-45.

Zhang M, Magit D \& Sager R 1997 Expression of maspin in prostate cells is regulated by a positive ets element and a negative hormonal responsive element site recognized by androgen receptor. PNAS 94 5673-5678.

Zhang YW \& Vande Woude GF 2003 HGF/SF-met signaling in the control of branching morphogenesis and invasion. Journal of Cellular Biochemistry 88 408-417.

Zheng DQ, Woodard AS, Fornaro M, Tallini G \& Languino LR 1999 Prostatic carcinoma cell migration via alpha(v)beta3 integrin is modulated by a focal adhesion kinase pathway. Cancer Research 59 1655-1664.

Zhou J, Scholes J \& Hsieh JT 2003 Characterization of a novel negative regulator (DOC-2/DAB2) of c-Src in normal prostatic epithelium and cancer. Journal of Biological Chemistry 278 6936-6941.

Zhu X \& Humphrey PA 2000 Overexpression and regulation of expression of scatter factor/hepatocyte growth factor in prostatic carcinoma. Urology 56 1071-1074. 
